Bu makaleye atıfta bulunmak için;

GÖNÜLLÜ TAŞKESEN, C. (2017), “Kırsal ve Kentsel Alanlarda Yaşlanma, Yaşlılık ve Yaşlılar: Denizli İli Örneği”, Mehmet Akif Ersoy Üniversitesi İktisadi ve İdari Bilimler Fakültesi Dergisi, 4(1), 92-124.

\title{
KIRSAL VE KENTSEL ALANLARDA YAŞLANMA, YAŞLILIK VE YAŞLILAR: DENIZLII İLİ ÖRNEĞİ
}

\section{AGING, OLD AGE AND ELDERS IN RURAL AND URBAN REGIONS: THE CASE OF DENIZLİ PROVINCE}

\author{
Canan GÖNÜLLÜ TAŞKESEN \\ Mehmet Akif Ersoy Üniversitesi, Çavdır MYO, Sosyal Hizmet ve Danışmanlık Bölümü, \\ cgtaskesen@mehmetakif.edu.tr
}

\section{ÖZET}

Toplam nüfus içindeki payı her geçen yıl artan yaşlılar yalnızca demografik özellikleri değil; sosyal özellikleri de etkilemeye başlamıştır. Gençlerin, yetişkinlerin ve yaşlıların yaşlılara yönelik değerlendirmeleri, araştırılması gereken bir konu haline gelmiştir. Her canlının normal şartlar altında yaşaması beklenilen bir dönem olan yaşlılığa; çeşitli yaş gruplarındaki bireylerin yükledikleri anlamlar önem arz eden bir konudur. Yaşlılara yönelik değerlendirmeler, toplumsal bütünleşmenin sağlanmasından, yaşlılara sunulan imkânlara kadar pek çok konuyu etkilemektedir.

Yaşlılar konusunda yapılan çalışmaların büyük kısmı; ekonomi, sağlık, hukuk, psikoloji gibi bilimler temelindedir. Araştırmanın özgünlüğü, yaşlılığa yönelik değerlendirmelerin toplumun her yaş kesiminden bireyleri tarafından nasıl şekillendiğinin; kırsal ve kentsel alanlar özelinde incelenmesidir. Araştırmanın sonucunda Türkiye'de yaşlılığa yüklenen olumsuz anlam tespit edilmiş ve gerekçeleriyle detaylandırılmıştır.

Anahtar Kelimeler: Yaşlı, Yaşlılık, Yaşlanma Sosyolojisi.

\section{ABSTRACT}

Elders, whose share in population are increasing every year, are not only affecting demographic characteristics; social characteristics have also begun to affect. Young people's,

\footnotetext{
* $\mathrm{Bu}$ araştırma, Süleyman Demirel Üniversitesi Bilimsel Araştırma Projeleri Koordinasyon Birimi Koordinatörlüğü'nce kabul edilen 4473-D1-15 numaralı proje kapsamında desteklenmiştir.
} 
adults' and the elderly's perception towards elderness has become a subject that needs to be investigated. The meanings that individuals in different ages load to the elderness which is a period that expected to be lived under normal circumstances, are important. The perception towards elderly influences many aspects such as social integration and opportunities offered to elders.

Much of the work done on the elderly so far are based on economics, health, law, psychology. The originality of the study comes from the investigation on the perception towards elderness and how it is shaped by individuals from all ages including rural and urban areas. As a result of the research, the negative meaning attached to elderness in Turkey has been determined and detailed with reasons.

Keywords: Elderly, Old Age, Sociology of Aging.

\section{GíRIŞ}

Gelişen ve değişen dünyada maddi kültür unsurlarının gelişmesi, toplumların her alanda refah seviyesine ulaşabilmesi için önemli adımlar atılmasına katkı sağlamaktadır. Teknolojideki yenilikler, tıp alanındaki gelişmeler, ortalama yaşam süresini artırmaktadır. Teknoloji ve tıp alanındaki gelişmeler; hastalıkların iyileştirilmesi, bebek ölüm oranlarının azaltılması gibi durumlara sebep olduğu için bireylerin daha uzun yaşaması söz konusu olmaya başlamıştır. Bunun yanında bireylerin daha bilinçli hâle gelmesinin, dengeli beslenmesinin, spor gibi rutinleri günlük yaşamlarına eklemesinin de bu konuda payı büyüktür.

Yaşlılığın tanımlanması, yaşlılığın ölçütleri dikkate alındığında çeşitli güçlükleri barındırmaktadır. Yaşlılık ve yaşlanmayla ilgilenen bilim dallarının hemen hepsi kendine has yaş, yaşlılık ve yaşlanma tanımları kullanmayı uygun görmektedir. Öyle ki; ortak bir yaşlılık başlangıç yaşı bile belirlenebilmiş değildir. Bu muğlaklıkla birlikte, Türkiye'de resmi olarak tanınan yaşlılık başlangıç yaşının 65 olduğu bilinmektedir.

Yaşlılığın belli başıı özelliklerinden bahsetmek mümkündür. Vücutta meydana gelen değişmeler yaşlılığın belirtilerinin arasında değerlendirilebilmektedir. $\mathrm{Bu}$ değişikliklerin doğrudan gözlemlenenleri olduğu gibi, doğrudan gözlemlenemeyenlerinden bahsetmek de mümkündür. Genellikle fiziksel değişmelerin görünürlüğü daha fazladır. Psikolojik ve sosyolojik değişmeler ise, dışarıdan bakıldığında kolaylıkla anlaşılabilir nitelikte değildir. 
Fiziksel değişimlerin yoğunlukla yaşandığ gündeme gelebilmektedir. Yaşlılıkta bakım konusu, tam anlamıyla bir sorun hâline dönüşebilmektedir. Türk toplumunun aile yapısından, değişen yaşam koşullarına kadar pek çok faktör; bakım konusunun bir sorun olmasına ya da olmamasına sebep olan durumlar olarak ortaya çıkmaktadır. Aile ya da ev ortamlarında yeterli bakım ve barınma imkânı bulamayan yaşlılar içinse kurum bakımı alternatifinden söz edilebilmektedir.

Günümüzde toplam nüfus içinde oranları giderek artıyor olsa da yaşlılar henüz ciddi bir sorun olarak nitelendirilmemektedir. Ancak neredeyse bütün göstergeler, konunun bir süre sonra büyük bir problem hâline geleceğini işaret etmektedir.

Araştırma açısından üzerinde durulmasının gerekliliğine inanılmış yaşlanma türü olan sosyal yaşlanmada bireylerin yaşlılıklarında görev ve sorumluluklarının farklılaştığına dair birtakım bulgulardan bahsedilebilmektedir. Yaşlıların toplumsal uyum süreçleri, yetişkinlerinki kadar kolay olamamaktadır. Yaşl1lıkla ilgili bakım sorunu ya da nüfustan kaynaklanan ekonomik sorunların yanında sosyal ve psikolojik sorunların olabileceğini söylemek doğru olacaktır. Yaşlılık döneminde yaşam doyumunun önemi, diğer bütün yaş dönemlerinden daha fazladır. Yaşlılığın yaşamın son dönemi olmasından kaynaklı olarak, yaşlı bireylerin üzerinde ölümün yaklaşmasının oluşturduğu bir baskının yanında, sosyal yaşamdan kısmen çekilmiş olmanın da baskısı rahatlıkla hissedilebilmektedir. Yaşam doyumunun sağlanamadığı durumlarda yaşlılık dönemi intiharlarının artış gösterdiği bilinmektedir.

Yaşlılığın sosyal boyutunu etkileyen bir başka durum da bireylerin yaşlılığa yönelik değerlendirmelerdir. Her yaş grubunun yaşlılığı anlamlandırması farklılık gösterebilmektedir. Görece daha genç insanlar yaşlılığı kendilerinden uzak bir süreç olarak değerlendirirken, çeşitli psikolojik, sosyolojik ve fiziksel değişimleri derinden hissetmeye başlayan insanlar yaşlılıkla ilgili farklı anlamlandırmalarda bulunabilmektedir. Yaşlılığın içselleştirmesi ve reddedilmesi durumları, yaşl1lık dönemlerinde bireylerin sağlıklı yaşlanmasının bir rolü ya da engelidir.

Toplumun yaşlıyı ve yaşlılığı nasıl değerlendirdiği, özellikle yaşl1lar için önemli bir konudur. Yaşlıların yalnızca tüketici konumunda olmaları, topluma katkılarından çok zararları olduğu gibi düşünceler; yaşl1ların sosyalizasyon sürecini sekteye uğratacak etkilere sebep olabilmektedir. Yaşlılığın toplumsal kabulü ise, problematik bir alan olarak görülen yaşlılık sürecine çeşitli sosyo-ekonomik çözümlerin getirilmesine kaynaklık edebilmektedir. 
Yaşlılığın değerlendirilmesi konusu, pek çok değişken özelinde incelenebilecek bir durumdur. Araştırma açısından önemli ana değişken kırsal ve kentsel alanlar olarak belirlenmiştir. Bunun yanında yaş, cinsiyet, eğitim durumu, gelir seviyesi, yaşlı bakım tecrübesine sahiplik durumu gibi değişkenler de yaşlılığın değerlendirilmesi konusunda etkili olabilmektedir.

Araştırmada kırsal ve kentsel alanlarda yaşlılığın nasıl değerlendirildiğiyle ilgili sorgulamalar yapılmıştır. Değerlendirme biçimlerinin gerekçeleri de derinlemesine incelenmiştir. Araştırma, kendinden sonraki araştırmalara kaynak olabilmesi adına, birçok farklı değişkenle yaşlanma, yaşlılık ve yaşlılar arasındaki bağlantıların açıkça ortaya konulmasını amaçlamıştır.

\section{YAŞLILIĞIN SOSYOLOJIK AÇIDAN İNCELENMESI}

Yaşlılık çalışmalarının artmasının gerekliliği, yaşanılan ülkelerin içindeki yaşlılık oranlarının nüfus bazında incelenmesi sonucu daha belirgin hâle gelmektedir. Bugünün Türkiye'si yaşlılık oranı açısından olması gereken bir çizgide gibi görünse de nüfusun yapılanması ve geleceği, ilerleyen zamanlarda, yaşlılı̆̆ın bir problem olarak ortaya çıkabileceğinin sinyallerini vermektedir.

Henüz Türkiye'nin yaşlı nüfusu, Batı toplumları ve Japonya'daki gibi yüksek oranlarda seyretmemektedir. Ancak Türkiye, bu toplumların geçirdiğine benzer bir demografik değişim süreci yaşamaktadır. Yaşlılık döneminin nitelikli yaşanmasını sağlamak için çeşitli politikaların geliştirilmesine olan ihtiyaç gün geçtikçe artmaktadır. Yaşlılığın başarılı bir şekilde gerçekleşmesi, yaşlanma ve yaşlılıkla ilgili toplum çapında bilgi edinilme ihtiyacını doğurmaktadır (ASPB, 2011: 1). Türkiye'de, yaşlanma olgusuna ne kadar çabuk reaksiyon gösterilirse, yaşlılığın ve yaşlanmanın olumsuz etkenlerini ortadan kaldırma ve olumlu etkenleri ortaya çıkarma süreci o kadar erken başlamış olacaktır (Tufan, 2003: 36).

\subsection{Kültür ve Yaşlılık}

Kültür değişmelerinin, toplumların hayat tarzlarını topyekûn değiştirdiği düşünülürse, bu değişmelere neden olan faktörler de şöyle sıralanabilmektedir (İşçi, 2007: 16);
a) Teknoloji faktörü
b) Fiziki çevre faktörü
c) Başka kültürlerle karşılaşmak
d) Kültürün kendi içinden gelen değişmeler vs. 
Teknolojik hızlı gelişmeler, sanayileşme, şehirleşme gibi faktörler, sadece aile kurumunu değiştirmekle kalmamış; sosyal kurumları, davranış örüntülerini ve hatta geleneksel değerleri de bazı değişikliklere uğratmıştır.

Geleneksel geniş ailede, genellikle aile içinde, neredeyse her yaştan üye bulunmaktaydı ve bu üyelerin, aile içinde çeşitli rol ve sorumlulukları vardı. Özellikle, ailenin en yaşlı üyesi, neredeyse ailenin en önemli üyesiydi ve aynı zamanda aile reisiydi. En yaşlı aile üyesi, bugün de hâlâ bazı etkileri görülen ancak geleneksel geniş aile yapısında baskın olarak hissedilen şu görevleri yerine getirmekteydi;

Koruyuculuk Görevi: Aileye, dışarıdan gelebilecek her türlü maddi ve manevi zararlara karşı, aile üyelerinin korunmasını ifade etmektedir. Koruyucu kimse, aynı zamanda ailenin sözcüsüdür ve aileyi toparlayıcı durumdadır.

Psikolojik Görev: Aile üyelerinin birlikte veya belli bir sosyal çevrede yaşamasından doğabilecek her türlü sıkıntıyı bertaraf etmeyi ifade eder. Bu görevin en güçlü yanı, aile üyeleri arasındaki sevgi bağının kuvvetlendirilmesidir.

Ekonomik Görev: Ailenin alışveriş ihtiyaçlarının ve birtakım ödemelerinin karşılanmasına yardımcı olmayı ifade etmektedir.

Torunlara Bakım ve Sevgi Verme Görevi: Ailenin en küçük üyelerinin, büyüklerinin kendilerine sevgi ve şefkat dolu yaklaşmalarına ihtiyaçları vardır. Özellikle her iki ebeveynin çalıştı̆̆ durumlarda, yaşlı bireylerin önemi daha çok artmaktadır. Bu görev, kuşaklar arası bağların kurulmasını ve ihtiyaçların manevi olarak karşılanmasını ifade etmektedir.

Dini Görev: Dini bilgilerin, çocuklara ve torunlara öğretilmesini kapsamaktadır. Dini bilgilerin yanı sıra toplumun ve ailenin kendine özgü âdetlerinin, gelenek ve göreneklerinin nesilden nesile aktarılmasını da içermektedir (Saygılı, 2011: 31-32).

Kültür konusunda en önemli değişim, insanların eskiden kültür varlıkları için ortak girişim ve uğraş sonucu ortaya koydukları kültürel ürünün çoğunluğunun tek bir kuşaktan meydana gelerek diğer kuşaklara aktarılması şeklindeyken; günümüzde, bu durumun nesillerin eşzamanlı olarak yaşamasından dolayı birlikte ortaya çıkardıkları ürün olarak kabul görmesidir. Yani öğrenilen şeyler eskiden bir kuşaktan diğerine aktarılırken, bu ürünlerin korunması ve alt nesile aktarılması bir görev ve zorunluluk niteliğindeydi. Günümüzde ise, bahsi geçen yaşam süresinin uzunluğundan dolayı, nesilden nesile kültür aktarımı durumundaki önem, özelliğini kaybetmiştir. Yaşlılar bugün torunlarının yaşlılıklarına şahit 
olabilecekleri yaşlara kadar yaşamakta ve uzun süre aynı kültürel atmosferde olduklarından dolayı, aynı kültürel öğeleri tecrübe etmiş hâlde olacaklardır (Tufan, 2003: 71).

$\mathrm{Bu}$ durumun değişmesinin çevresel kaynaklı birçok faktörü bulunmaktadır. Kültürün kuşaktan kuşağa aktarılması durumu, yaşlılara verilen değer ve önemle de doğrudan alakalıdır. Yaşlıların aile içinde otorite sayılmaları, yaptıkları birçok şeyin taklit ve öğrenme yoluyla diğer nesillerce kabul görmeleri, onlara yüklenilen bu görevle de alakalıyken; bugün kültürün aktarılmasının tek öğesi, yaşlıların yaşantıları ve öğretileri olmamaktadır. Kültür değişim hızı da günümüz şartlarında değerlendirildiğinde, özellikle kültürün başka kanallar yoluyla aktarılmasının ne kadar hızlı olabileceği görülmektedir. Ayrıca, kültürlerarası etkileşimin, kültürel öğeleri daha hızlı değiştirdiği varsayılırsa, günümüzde yaşlıların kültürel değerleri ile gençlerin kültürel değerlerinin de birbirleriyle örtüşmediği de görülebilmektedir.

Değişen kültür ile birlikte, farklı problemlerin ortaya çıktığına daha önce değinilmiştir. $\mathrm{Bu}$ problemlerden biri de yaşlıların yalnızlaşmasıdır. Bu durumun iki önemli nedeni vardır. İlki; yaşam süresinin uzaması ve kadınların erkeklerden genel olarak daha uzun ömürlü olması ile özellikle kadınların yaşlılıklarında dul olarak yaşamlarını sürdürmesine sebep olmaktadır. Bu durum erkekler için de benzerlik taşımaktadır. İkinci önemli sebep ise; boşanma oranlarının artmasıyla birlikte, yaşlıların yaşlılık dönemlerini eskiye nazaran daha büyük oranda yalnız geçirmesidir. Kadınlar, ileri yaşlara kadar kendilerini başkalarına bağımlı hissetmeseler de erkekler için durumun böyle olmadığı ortadadır. Bu yüzden, önümüzdeki yıllarda, yaşlılara sunulan yardımlarla erkeklerin daha fazla ilgilenmek zorunda kalacakları söylenebilir. Diğer taraftan iki kişilik hanelerin sayısı da artış göstermektedir. Bu durumun sebebi ise, yaşam ömrünün uzun olması dolayısıyla eşler, yaşlılık yıllarında daha uzun süre birlikte yaşamaktadır. Ayrıca, geleneksel geniş aileden çekirdek aile yapısına geçilmesinin bu durumla doğrudan ilgisi vardır (Tufan, 2003: 54). Maddi ve manevi kültür unsurlarında meydana gelen değişmelerden sonra, günümüz yaşlısının yaşam biçiminin, çalışma ve aile ilişkilerinin, kullandıkları araçların, düşüncelerinin ve daha pek çok şeyin değiştiğini söylemek yanlış olmayacaktır.

\subsection{Değer ve Yaşlılık}

Değer kavramına terimsel olarak göz atıldığında, bireylerin objeleri, diğer bireyleri, durumları ve hareketleri nasıl algıladığına ya da algılamadığına atıf yapılması gerekir. İyi, kötü, arzulanan istenmeyen ve buna benzer yargıları oluşturan standartlar ve prensipler esasen değer kavramının kendisini oluşturmaktadır (Halstead ve Taylor, 2000: 169). 
Değerler, bireylerin davranışlarına yön verme yetisine sahiplerdir. Bireylerin, kendileri ya da bir başkasıyla ilgili davranışlarına yön verip davranış kılavuzu olma görevini üstlenmektedir. Aslında her birey, kendisine göre önemli sayılabilecek değerler için çaba gösterme olanağına sahiptir. Toplumdaki bütün bireyler, toplumsal çevrede hangi davranışların geçerli, hangilerinin geçersiz olduğuna ilişkin önceden belirlenmiş ve toplumda yer etmiş değer yargılarıyla karşılaşırlar. Bireyler ahlak ölçülerini, birtakım kavramlarla belirleyebilmektedir. Kişiler birtakım toplumsal kuralları, gelenekler ve görenekler yoluyla almaktadır. Örneğin iyi-kötü, doğru-yanlış gibi kavramların bu çerçevede değerlendirilerek toplumsal kuralları şekillendirebildiği görülmektedir (Beill, 2003: 13-14). Değerlerin kültürle olan ilişkisi, değerlerin de özünde öğrenilen bir tarafının olduğunu göstermektedir. Toplumsal değer kavramı incelendiğinde, bireylerin davranışlarının ne yönde şekillendiği, hangi noktalarda ve nelerden etkilendiği görülebilmektedir.

Yaşlılığa yüklenen anlamlar toplumdan topluma değişebileceği gibi kişiden kişiye de değişiklik göstermektedir. Günümüzde yaşl1lık, yaşamın önemli bir bölümünü kapsar hâle gelmiştir. Artan yaşam süresinin bu durumla doğrudan etkisi vardır. Bununla birlikte, yaşlanmanın kaçınılmaz bir son olması, bireylerin yaşlanma arzusuyla ters düşebilmektedir. Özellikle çalışma hayatının içinde olan bireyler, emekliliklerinin hayalini kurabiliyorken, kimi bireyler de yaşlılıkla birlikte gelebilecek sosyal, fiziki, ekonomik olumsuzlukları düşünerek yaşlanmayı istemeyebilirler. Bazı yayın organlarında, yaşlılıkla ilgili yapılan propagandalar da insanların yaşl1lıkla ilgili düşüncelerini olumlu ya da olumsuz etkileyebilmektedir.

Yaşlılığa toplum tarafından yüklenen sosyal anlamların büyük bir bölümü, yaşlanmanın fiziki ve zihinsel yetiler üzerindeki etkileri konusunda hatalı inançlarla ilgilidir. Yaşl1lık, tek başına ve özünde; düşüncede katı olmaya, unutkanlığa ya da sevilen birçok faaliyetin yapılamamasına neden olmamaktadır. Hatta birçok insan için yaşlanma çoğunlukla ve büyük oranda tolere edilebilen, yaşantı üzerinde etkisinin az olduğu dereceli bir değişim süreci olarak algılanıp yaşanılabilir. Yaşlılığa yüklenen sosyal gerçeklik, bireylerin yaşlanırken yaşadıkları değişikliklerin önemi, anlamı ve etkileri konusunda son derece önemli bir etkiye sahiptir. Yaş; toplumsal olarak birçok sosyal rolün kazanılmasında ve hatta kaybedilmesinde, davranış örüntü ve kalıplarında, kaynak ve firsatların sosyal dağılımında, bireyleri sınıflandırmada önemli bir gösterge olarak kullanılabilir (Morgan ve Kunkel, 1998: $6)$.

"Yaşlılığa yüklenen anlamlar, yaşlı kişinin toplum içindeki konumunu değiştirmekte, fiziksel etkinliklerin azalmasıyla birlikte yaşlının toplumdan uzaklaşmasına ve 
soyutlanmasına neden olmaktadır. Aynı şekilde toplum da yaşlıdan uzaklaşmakta, yaşlılığın 'bilge'liğinden yararlanmak yerine, daha 'dinamik' olarak nitelendirilen gençler tercih edilmekte, yaşlı-toplum arasındaki mesafenin artması kişinin 'yaşlı hissetme' algısını pekiştirmektedir. Oysa yaşlılığın bilgeliği ve gençliğin dinamizminin birlikte yer alması daha verimli ve üretken toplumlar oluşmasına katkı sağlar.” (Kalkan, 2008: 5).

\subsection{Toplumsal Roller-Beklentiler ve Yaşlılık}

Toplum içinde, bireylerden beklenilen, normal karşılanan ve olması gerektiği düşünülen birtakım davranışlar vardır. Toplumun bireylerden beklediği bu davranışlar, toplumsal rolleri oluşturmaktadır. Toplumsal roller her toplumda farklılaşabilmektedir. Örneğin yaşl11ık bir roldür ve toplumun yaşlı olarak nitelendirilen bireylerden davranış bazında beklentileri vardır. Diğer taraftan statülere ve cinsiyete özgü beklenti kalıplarının olduğundan da bahsedilebilmektedir (Zencirkıran, 2015: 86-87).

Yaşlanmanın en belirgin özelliklerinden biri olan ağarmış saçlar ve kırışmış cilt, yaşlıların fiziksel ya da bilişsel fonksiyonlarının üzerinde herhangi bir etkiye sahip değildir. Ancak buna rağmen, toplumsal ilişkileri ve rolleri düzenlemede bir kıstas olarak alınabilmektedir (Morgan ve Kunkel, 1998: 6).

Toplumsal roller ve beklentiler de toplumlara özgü olabilmektedir. Aynı rollerden farklı toplumlarda aynı beklentilerin olmasına rastlanılabiliyorken, farklı beklentilerin olması durumu da söz konusu olabilmektedir. Rollerin değişmesi, kültür kaynaklı etkenlere dayanmaktadır. Toplumların, kategorileştirdiği mesleklere, cinsiyetlere, yaşlara, medeni durumlara, ırklara biçtiği roller toplumların öğrenmişlikleriyle alakalıdır. Toplumsal rollerini yerine getirmeyen insanlar, toplumsal birtakım tepkilerle karşılaşabilmektedir.

Yaşlılık konumunu dolduran birinden beklenilen geleneksel birtakım davranışların olması toplumda kabul edilebilir bir durumdur. Ancak bireysel özelliklere göre her toplumsal rolde olduğu gibi beklenilen davranışların dışına çıkılması da söz konusu olabilmektedir.

Türk toplumunda yaşl1lardan beklenilen toplumsal roller; ailenin bütünlügünü sağlama, gerekli durumlarda bakıcılık görevini üstlenme gibi şeyler olabilmektedir. Bununla birlikte, yaşı bir bireyin örneğin fiziksel aktiviteleri aktif olarak yapması beklenmeyen bir durum olarak karşımıza çıksa da bu davranışı sergileyen kişiler kabul görebilmektedir. Giyim kuşam konusunda da toplumun birtakım beklentilerinin olması söz konusu edilebilmektedir. Çok renkli, daha çok gençlerin kullandığ çevreden gelebilecek etkiler olumsuz olabilmektedir. 
Toplumsal roller ve beklentiler, aynı toplumun farklı kesimlerinde bile farklılık gösterebilir yapıdadır. Teknoloji kullanımı, günlük yaşam aktiviteleri, kişiler arası ilişkiler, din, kadın-erkek rolleri gibi pek çok konuda beklenilen davranış ve roller yaşanılan yer özelliklerine göre, sosyo-ekonomik koşullara göre, kültürel özelliklere göre ve hatta içinde yetiştikleri aile yapılarına göre şekil değiştirebilmektedir.

\subsection{Normlar ve Yaşlılık}

Normların, yasa ve yönetmelik gibi formel düzenlemelerle ya da gelenekler gibi yazılı olamayan kurallarla biçimlenmesi söz konusu olabilmektedir (Zencirkıran, 2015: 65).

Homans normların, grup üyelerinin zihinlerindeki düşünceler doğrultusunda, belli durumlarda bireylerin ne yapması gerektiğini ve ne yapılmasının beklendiğini belirten niteliğinin olduğunu belirtmiştir. Ayrıca ona göre normlar, öneri biçiminde ortaya sürülen fikirler aracılığıyla bir yaptırım kalıbı niteliğindedir. Normlar, kendileri davranış olarak adlandırılamazken, bireylerin davranışlarının nasıl olması gerektiği üzerine düşüncelerdir (Homans, 1971: 88).

Araştırma 1şığında incelendiğinde, her yaş kategorisi için, toplum tarafindan kabul gören ya da görmeyen davranış kalıplarından bahsedilebilmektedir. Bu kalıplara yaş normu adı verilmektedir ve üç temel özelliğinin olduğu varsayılmaktadır. Bu temel özelliklerin ilki, uygun ve uygun olmayan davranışların neler olduğunun belirlenmesidir. İkincisi belirli toplumsal gruplar tarafından ortak olarak paylaşılmalarıdır. Yaş normunun üçüncü özelliği ise, sosyal ilişkilerde sınırların ihlal edilmesi durumunda, sosyal kontrol ve yaptırım mekanizması sunmasidır (Victor, 2005: 39).

Yaş normunu biraz daha açmak gerekirse, toplumdan topluma değiştiğine de vurgu yapmak gerekmektedir. Kırsal alanlarla kentsel alanlar karşılaştı̆̆ında bile bu değişkenlik göze çarpmaktadır. Örneğin, kentsel toplumlarda, kişilerin 20'li ya da 30'lu yaşlarda evlenmesine yönelik bir yaş normundan bahsedilebilmektedir. Burada yaş normunun, rollerle bağlantılı olduğu da dikkat çekmektedir. Kişilerin belirli sosyal rollere de hangi yaş aralıklarında gireceklerine ilişkin toplum üyelerince paylaşılan fikirler de yaş normunun kapsamındadır (Morgan ve Kunkel, 1998: 193). Kırsal bölgelerdeki, evlenme yaşı ile kıyaslandığında, kent toplumlarından evlilik yaşının dahi değişkenlik göstermesi, durumun örneklerinden sayılabilmektedir.

İnsanların yalnızken farklı, grup içinde daha farklı davranış sergileyebilirler. Bir kişinin, başka bir kişiden ya da kişilerden etkilenerek davranışlarına yön vermesi sosyal 
etkidir. İnsanların başkalarından etkilenerek davranışta bulunması da sosyal davranış olarak adlandırılmaktadır (Göksu, 2007: 129). Araştırma açısından sosyal etki kavramı önemli bir kavramdır. Yaşlılara saygı gösterilmesinin önemli olduğu bir grupta bu davranış eğiliminde olmayan bir birey de sosyal etkiden dolayı, bu davranışı gösterme yolunu seçebilmektedir. Grupların, toplulukların, toplumların değer yargılarından daha belirgin olanlarında sosyal etkinin derecesinin de artacağı söylenebilmektir.

Sosyal etki konusunda da yaşlılık özelinde; yaşlıların gençlerden ve toplumdan etkilenmesi ile toplumun diğer yaşlılarının referans grup olarak ele alınmasından bahsedilebilmektedir. Huzurevinde yaşayan bir yaşlı ile -örneğin- yaşlı dostu kentlerde yaşayan bir yaşlının davranışları arasında farklılıklar görmek mümkündür. Sosyal etkinin her iki grup için de ortaya çıktığı gözlemlenebilmekte ve söylenebilmektedir.

\section{5. İnançlar ve Yaşlılık}

"Bir inanç, ferdin dünyasının bir yönüne ait idrak ve bilgilerin devamlı bir organizasyonudur. Bir inanç, bir şeyin ifade ettiği manalar bütünüdür, ferdin eşya hakkındaki bilgisinin toplamıdır. Bir idrak veya bilgi bizatihi bir organizasyon olduğu nispette, inanç da bir organizasyonlar organizasyonudur. Dolayısıyla tamamlanmış ve yapılanmıştır.” (Krech ve Crutchfield, 1980: 179).

İnançlar, genel olarak, gerçekliğin doğası sorgulamasından ortaya çıkan, ileri sürülen fikir ve iddialar yani bireylerin dünya hakkında paylaştıkları fikirleridir. $\mathrm{Bu}$ açıdan bakıldığında, bilgi kaynağı olarak geçmişin yorumlanması, bugünün açıklanması ya da geleceğin tahmini kullanılabilmektedir. Bunlarla birlikte, sağduyu, din ya da bilim de veyahut bunların karışımı da temel alınabilmektedir. İnançların bir kısmının maddi olmayan şeyler olduğunu söylemek mümkündür. Evrensel olarak bakıldığında, bütün kültürlerde, sahip olunan inançların yalnızca bir kısmının ispatlanabilir nedenlere dayandığını bir kısmının da makul temellerden uzak olduğu görülmektedir. Değerlendirici olarak tabir edilen inançlar, insanlara spesifik olay ve durumların yorumlanması ya da tasavvuru için entelektüel ve duygusal aletler vermektedir. Örneğin, geleneksel aile değerlerine inanan bir birey için, toplumda meydana gelen birçok aksaklığın sebebi, aile kurumunda meydana gelen çözülme olabilmektedir. Ampirik olarak tabir edilen inançlar ise, ne olması gerektiğinden ziyade, ne olduğunu ifade eden inanç türüdür. Ampirik inançlar, insanların inandıkları gerçeğin algısını da şekillendirmektedir. Bir ırkın diğer bir ırktan üstün olduğuna inanmak bu inanç türünün örneklerindendir (Bozkurt, 2015: 97-98). 
Yaşlılık ve inançlar, çok yönlü olarak ele alınması gereken bir bağlantıdır. Yaşlıların yaşlılık konusundaki inançları, diğer insanların yaşlılık ve yaşlılar konusundaki inançları; yaşlıların hayata dair inançları, diğer insanların yaşlılıkta hayata dair inançları ve buna benzer pek çok konu bu bağlantının içine dâhil edilebilmektedir.

Yaşlılığın ne olmadığını inceleyen Akçay, eserinde şunları söylemektedir (Akçay, 2011: 20);

- Yaşllılık, çaresiz bir hastalık değildir.

- Yaşlılık, hayatın son dönemi değil, ikinci dönemidir.

- Yaşlılık, her şeyin kötüleş̧tĭ̆i bir dönem değildir. Bazl şeyler kötüleşirken, bazı şeyler iyileşir.

- Yaşlılık, belli, değişmez bir yaşta ve topyekün bütün organlarda başlamaz.

- Yaşlılık, herkeste aynı gelişen bir süreç değil, bireyseldir.

$\mathrm{Bu}$ gibi inanışlar yaşlılığa ortak bir bakış açısı geliştirmenin ve yaşlılık hakkında olumsuz düşüncelerin sonucunda ortaya çıkmıştır. Ancak yaşlılıkla ilgili inançlar sadece bunu kapsamamaktadır. Bu inançların olumlu biçimleri de yukarıdaki maddelerde yer almakta ve birtakım yaşlılar ve yaşlı olmayanlar tarafindan kabul görmektedir. Üzerinde durulması gereken diğer noktalar, yaşlılığın fiziksel, psikolojik, sosyolojik yönlerine; emekliliğe, bakıma kadar pek çok inançların da olabileceğidir.

Günümüzde yaşlılık algısının medya, politikalar, kanaat önderleri, yaşlılar, gençler, kısacası toplumda yer alan maddi, manevi kültür öğeleri ve toplumu oluşturan bireyler tarafından şekillendirildiği göz önünde bulundurulmalıdır.

\section{6. Önyargılar ve Yaşlılık}

Genel olarak bakıldığında önyargının, bir olay, durum, nesne, kişi hakkında çoğunlukla aleyhte bazen de lehte olarak, önceden çeşitli sebeplerle oluşturulmuş kanaat ya da yanlılığın olduğu söylenebilmektedir. Bu yanlılığın bahsedildiği üzere olumlu ya da olumsuz olabileceğini unutmamak gerekmektedir. Önyargılara yaygın olarak negatif bir anlam yüklenmekte ve yüklenen bu anlam çerçevesinde önyargılar, tutumların gelişmesinde genellikle olumsuz yönde etkili olmaktadır. Önyargılar, gerçeklik karşısında sınanmamış, daha çok önyargı sahibi bireyin kendi duygu ve tutumlarına bağlı olarak stereotipleştirilmiş inançlarla karakterize edilmektedir (Marshall, 1999: 559).

Yaşlılıkla ilgili önyargılar, genellikle yaşlı ayrımcılığı olarak nitelendirilecek düzeye ulaşabilmektedir. Yaşlı ayrımcılığının teorik temelleri de yaşlılık hakkındaki görüşlerden ileri 
gelmektedir. Yaşlılığın ölüme en yakın dönem olmasından ve ölümden duyulan korkuda; gençliğe, fiziki güzelliğe ve cinselliğe verilen önemin yanında ekonomik olarak üretkenliğe verilen önemin de etkisi bulunmaktadır. Ayrıca yaşlılık üzerine yapılan araştırmaların önemli bir kısmının huzurevleri, bakımevleri ya da hastane gibi ortamlarda bulunan yaşlılarla ya da onların sorunlarıyla ilgili yapılması da bu duruma neden olabilmektedir (Çilingiroğlu ve Demirel, 2004: 225).

Bugünün toplumlarında genç bedenler üzerinde yapılan vurgular daha çok güzellik, enerji, zarafet, iyimserlik, maddi ve manevi dayanıklılık üzerinde yoğunlaşmaktadır. Yaşlı bedenler üzerinde yapılan vurgular ise, daha çok çirkinlik, acziyet, yetersizlik üzerinde yapılmaktadır (Bond ve Corner, 2004: 59).

Önyargıların ne yönde olduğu/olacağıyla ilgili de birtakım etkenler vardır. Kültür; bunların başlıcasıdır. Daha çok bedensel özellikler üzerinde oluşan önyargılar, öğrenme yoluyla aktarılır. Örneğin, Çin'de yüksek statü işareti ve bilgelik ifade eden yüzdeki kırışıklıklar, Batı kültüründe bedensel ve ruhsal çöküşün işareti olmaktadır (Featherstone Hepworth, 1993: 306). Kültürün yansıması olan bu anlayış özellikle kadınlar üzerinde etkilidir ve vücuttaki kırışıklıklar, bir an önce kurtulunması gereken bir olumsuzluk çağrıştırmaktadır. Genç kadınların bile yaşlanmaya olan önyargıları nedeniyle henüz kırışıklıkları oluşmadan, çeşitli uygulamalarla oluşmamaları için önlemler almakta ya da oluşmaya başladığı andan itibaren, kurtulmanın her türlü yoluna başvurabilmektedir.

Yaşlıların toplumda sayılarının artmasına bağlı olarak toplum içinde daha görünür hâle gelmeleri, yaşlıların dezavantajlı bireyler olduğu yönündeki düşünceleri ve onların dezavantajlı duruma girmesine neden olan tutum, ayrımcı uygulamalar ve düşüncelerle mücadele etme olasılığını artıracaktır (Morgan - Kunkel, 1998: 7).

\subsection{Kitle İletişim Araçları ve Yaşlılık}

Medya, üzerinde birçok çalışma yapılmış alanlardan birdir. Bu çalışmaların ortak yönleri olsa da medya hakkında birbirleriyle çelişen fikirler de ortaya sürülmüştür. Örneğin, birtakım çalışmalar, medyanın gündemi belirlediği ve toplumun düşünce ve kanaatlerinin olmasına yardımcı olduğunu vurgularken; diğer çalışmalar, medyanın kanaat ve tutum oluşturmaktan ziyade, çevresel etkilerle oluşan olgu, tutum ve davranışları pekiştirdiğini savunmaktadır. Medyanın aslında bireyler üzerinde ikincil etkisi olduğu düşünülmektedir. Medyanın aynı zamanda fikirleri yayma özelliği bulunmaktadır. Bu özelliğin, bireylerarası ilişkilerle birleştiğinde ve medyanın var olan ikna etmekten çok destekleme rolünde 
bulunmasına bağlı olarak arttığı düşünülmektedir (Picard, 1991: 45). Kültürel öğelerin aktarımı, neyin normal kabul edilip neyin reddedileceği, toplumun hassas noktaları gibi durumlar, medya tarafından üretilmese de medya tarafından yayılmaktadır. Uzun süre, aynı görüşün servis edildiği durumlarda ise, medya aracılığıyla tutumlara yansıyan bazı özelliklerin belirmeye başladığı gözlemlenmektedir.

Kitle iletişimi, yalnızca siyasi içerikli yayınlar yapmamakta, günümüzde birçok ses ve görselle hayatımızın her alanında bulunmaktadır. Kitle iletişimin en yaygın olduğu alanlardan biri şüphesiz televizyonlardır. Erişimin ve ulaşımın kolay olması bakımından günümüzde halkın büyük bir yüzdesine ulaşabilir hâldedir. Özellikle televizyonda yayınlanan haberler, eğlence programları, reklamlar ve daha pek çok yayın, toplumun tutumlarını değiştirme potansiyeline sahiptir. Örneğin, yaşlıların toplum içinde saygı görmesini "olması gereken" olarak servis eden kitle iletişim araçları, bu görüşün toplumda kabul görmesi konusunda önemli bir yere sahip olacaktır. Bununla birlikte, yaşlıların artık toplumda bir yük olduklarını, işe yarar bir özelliklerinin kalmadığını, toplumun içine karışmalarının gereksiz olduğunu servis eden medya araçları, bir süre sonra toplumda bu düşüncenin yaygınlaşmaya başlamasına da sebep olabilmektedir. Bunun örneklerini, Avrupa'da birtakım ülkelerde görmek mümkündür.

Yaşlılığın sunum biçimi, birçok söylem gibi yine sosyal bir inşa ürünüdür. Bunun en önemli göstergelerinden biri de bedensel gerilemeye yapılan aşırı vurgu olarak karşımıza çıkmaktadır. Yaşlılık, sunumu itibariyle birçok fiziksel kaybı çağrıştırır hâle gelmektedir.

Kitle iletişim araçlarıyla ilgili pek çok mesaj, genç görünmenin yaşlanmaktan daha değerli olduğuna vurgu yapmaktadır. Tüketim toplumu olarak adlandırılan günümüz toplumlarında, böyle bir değerin vurgulanması, yaşlılığa ilişkin olumsuz bir dil ve imajı güçlendirmektedir (Powell ve Longino, 2002: 222). Yaşlılığın, gençlikle yapılan karşılaştırılmalarında ve yüklenen olumsuz anlamlarındaki mesaj, genç ve yaşlı bedenler arasındaki ayrım silikleştirilmeli veya silinmeye çalışılmalıdır şeklindedir. Günümüzde ayrıca bütün yaş gruplarının tüketim örüntüleri incelendiğinde, ortaya çıkan tablo benzer özellikler taşımaktadır. Yaş reddedilerek tüketimin, popüler kültürün bir ürünü olması söz konusu olabilmektedir ve bu görüş sürekli olarak pekiştirilmektedir (Gilleard ve Higgs, 2005: 73).

Yaşlanmanın etkilerinin gizlenmeye çalışılması, üzerine en çok vurgu yapılan durumlardan biridir. Bunun için özel olarak üretilmiş ve yaşlanmanın özellikle ciltteki etkilerini en aza indirici olarak nitelendirilmiş ürünlerin, kitle iletişim araçlarında bolca yer 
alması, aynı zamanda gençliğin yaşlılıktan daha değerli olduğu mesajını da pekiştirmektedir. Bunu yaparken yaşlılığın yetersizliğini de vurgulamak olarak değerlendirilebilmektedir.

Bununla birlikte, yaşlılığın yalnızlığı, muhtaçlığı, işe yaramazlığı, çağrıştıran ve yaşlıların toplumdan çekilmesini, kuşak çatışmasını özenle işleyen reklamlar, diziler, filmler, haberler de mevcuttur. Bütün bu temsiller kadar, yaşlılı̆̆ın emeklilik dönemlerinde torunlarla, aileyle birlikte mutlu geçirilen günlerin bir aracı olduğu vurgusuna da rastlanılmaktadır. Bütün bu anlatılanların ışığında söylenebilmektedir ki; yaşlılık konusundaki fikirlerin altında yatan sebeplerin bir kısmı medya aracılığıyla servis edilmiş ve özümsenmiş olabilmektedir.

Yaşlılık ve kitle iletişim araçlarının ilişkisi, yaşlılığın kitle iletişim araçlarındaki temsilinden ibaret değildir. Yaşlıların medyayı ya da kitle iletişim araçlarını nasıl ve ne amaçla kullandığı da araştırma için önemli bir konudur.

Literatürde yaşlıların kitle iletişim araçlarını kullanması üzerine birçok çalışma mevcuttur. Televizyon izleme alışkanlıkları, gazete okuma alışkanlıkları, radyo dinleme alışkanlıkları, internet kullanma alışkanlıkları birçok kez incelenmiştir. Günümüzde yaşlıların kitle iletişim araçlarını kullanması, televizyon üzerine odaklanmıştır. Gazete okuma alışkanlıkları diğer yaş gruplarına göre daha fazladır. Radyo televizyon henüz yaygınlaşmadan önce birincil bilgi kaynaklarından biri hâlindeydi. Günümüzde daha çok müzik yayını yapılan bir kitle iletişim aracı hâline gelmiştir. Hâl böyle olunca, radyoyu en fazla kullanan yaş grubu, gençlerden oluşmaktadır. Yaşlıların radyo kullanma alışkanlıkları, giderek azalan bir ivmeye sahiptir. Yaşlıların internet kullanımı da giderek değişmektedir. Artan bir şekilde yaşlıların hayatlarında yer alan internet, sadece ekran karşısında tek yönlü bir ilişkiden ziyade, değişen yaşam koşullarıyla birlikte, yaşlıların uzaktaki çocuklar ya da torunlarla interaktif biçimde iletişim kurulmasının aracı hâline gelmiştir (Koçak ve Terkan, 2010: 50-71).

\section{YAŞLILIKLA İLGILİ BAZI SOSYAL PROBLEMLER}

\subsection{Yaşıılık, Çalışma Hayatı ve Emeklilik}

Emeklilik bireyler için sadece çalışma hayatı ya da ekonomik ilişkileri kapsayan bir kavram değildir. Emeklilik, neredeyse bütün disiplinlerin araştırma alanı olabilecek kadar çok yönlü bir kavramdır.

Emeklilik, iş yaşamının sona ererek ekonomik durumun azalması ve iş yaşamında edinilen arkadaşlık ilişkilerinden kısmen de olsa uzaklaşılması anlamını taşımaktadır. Genellikle emekli olan kişiler, kazançlarını eskiye oranla kaybettiklerini ve insanlarla her gün 
temas etme fırsatını kaçırdıklarını söylemektedir. Ancak emekli olan kişilerin birçoğu durumunu kabullenip yeni uğraşlar bulma yoluna yönelmektedir. Özellikle emeklilik, kişinin kendi isteğiyle, beklenen bir zamanda olmuşsa ve yeterli bir gelir elde ediliyorsa; emekliliğe uyum sağlamak çok daha kolay hâle gelmektedir (Saygı11, 2011: 20). Emekli olmayı etkileyen birtakım faktörler vardır. Bunlar; birey için çalışmanın anlamı, işin niteliği, bireyin işteki konumu, emeklilik için ne derece hazır olduğu, emeklilik ortamının niteliği ve görünümücazibesi, diğer toplumsal koşullar (çalışmanın, yaşlılığın toplumsal anlamı), çalışma yaşamının niteliği, yasalarla düzenlenmesi, çalışma ve emeklilik olgusu ile ilgili diğer çağcıl değişmeler, bireysel özel koşullardır (Akçay, 2011: 206).

Emeklilik sürecinin bir sorun olmaması, kişinin çalışma hayatından nasıl ve ne sebeplerle ayrıldığıyla da ilişkilidir. Kişi zorunlu olarak emekli olma yoluna itildiyse, belli olumsuzluklardan sonra bu eylemi gerçekleştirdiyse ya da meslek yaşamı son derece sancılı bir kopuşa uğradıysa, kişinin çalışma hayatı sonrasında karşısına çıkacak durumla nasıl baş edeceğini bilmiyorsa, emekliliğin son derece yıkıcı bir durum olması muhtemeldir (Tufan, 2003: 49). Bir birey, çalışma hayatında aktif olarak yer alması gerektiğini düşünüyorsa ve henüz emeklilik planları yapmıyorsa, bir bakıma kendini hâlâ üretken neslin içinde konumlandırıyor demektir. Fiziksel olarak iş hayatında bulunma yeterliliğine inanıyor ve psikolojik olarak da çalışma hayatının içinde olduğu zamanlarda kendini gerçekleştirebildiğini düşünüyorsa, emeklilik bu hâlde birey için tam bir yıkım hâlini alabilmektedir. Bu birey için emekli olmak demek, gelirde azalmanın yanında boş zamanların artması ve boş zaman planlamasının henüz yapılmamış olması anlamına gelebilmektedir. Bireylerin emeklilikten sonra bir "boşluk" hâline düşmesi, hayatının geri kalanı için çok sancılı bir sürecin başlaması anlamina gelebilmektedir.

Bir birey, kalifiye eleman olarak yeterince uzun bir süre iş hayatında bulunmuşsa ve ekonomik gücü yeterliyse, iş hayatından erken ayrılma bu birey için kazanç sayılabilir. Çünkü bu imkânlara sahip olan insanlar, aktif olarak çalışma hayatının içinde yer aldıkları zamanlarda firsat bulup yapamadığı birçok uğraşı ancak emeklilik dönemlerinde gerçekleştirebilmektedir. Ancak orta yaşlardan itibaren işsiz kalmış ve iş bulamamış insanlar erken yaştan itibaren çalışma hayatının dışına itilmeleri dolayısıyla, emekli maaşları da düşük olmaktadır. Zaten ekonomik yetersizlikleri nedeniyle sosyal yaşamları bozulan kişilerin, yaşlılık dönemi sorunlarının arasına düşük gelir de eklenmektedir (Tufan, 2003: 51). Her durumda yaşlılık dönemi depresyonlarının görülmesi muhtemeldir. Ancak bu gibi 
tetikleyiciler, bu depresyonların şiddetini artırmaktadır. Durumun sadece psikolojik ya da sosyolojik boyutunun olduğunu düşünmek de çalışmanın eksik kalmasına yol açabilecektir.

Bireylerin, erken yaşta çalışma hayatının dişında kalmaları, toplum açısında da sıkıntılı bir durumdur. Erken yaşta emeklilik özünde, üretimin içinde aktif olarak yer alan kesimin sırtındaki yükün artması anlamına gelmektedir. "Sosyal güvenlik sisteminin işlevini yerine getirilmesini sağlamak için daha fazla sosyal kesinti ödemek zorunda kalanların yaşam standardını tehdit eden bu durum, yaşlıların toplumdaki konumunu da olumsuz etkilemektedir." (Tufan, 2003: 51).

Emeklilik sürecine iyi hazırlanan bireylerin, emeklilik sonrası birtakım planları olabilmektedir. $\mathrm{Bu}$ planların uygulanması, emekliliğin beklenilen bir durum olması ve hazırlanılması bakımından çok daha kolaydır. Örneğin; henüz küçük torunlar varsa, onları sık sık ziyaret ederek kendi çocuklarını biraz olsun rahatlatma ya da torunların bakımını tamamen üstlenerek bakıcı görevini üstlenme gibi durumlar görülebilmektedir. Emeklilik sonrası artan zamanlarda kadınlar çocuklarının daha çok ev işlerini üstlenirken; erkekler torunları parka götürme gibi görevleri üstlenmektedir. Emeklilik sonrası sosyal hayatta da meydana gelebilen arkadaşlık ilişkilerinin azalması, böylece dışarıda edinilen yeni arkadaşlıklarla telafi edilebilmektedir.

\subsection{Yaşlılık ve Bakım Sorunu}

Yaşlanma, özünde kişisel bir sorun olarak görülse de fiziki ve psikolojik yetersizlikler ortaya çıkmaya başladığında ve gelir seviyesini düşürdüğü andan itibaren bireysellikten çıkarak toplumsal bir sorun hâline gelmektedir. Bireyler, yaşlanmaları dolayısıyla kendi geçimlerini devam ettirebilecek ve garanti edecek bir gelire sahip değilse, sosyal yardımlara muhtaç hâle gelebilmektedirler. Herhangi bir fiziksel ya da psikolojik nedenle yardıma ve bakıma muhtaç olan kimselere, aile fertlerinden biri, arkadaş çevresi, herhangi bir ücret karşılığında ya da ücretsiz olarak ihtiyacı karşılayacak olan yardımcılar bakım vermek zorunda kalmaktadır. Yaşıı insanların ekonomik güvencesinin sağlanması bu bakımdan da önemlidir. Çoğu yaşlı insan için, yaşlılık dolayısıyla iş hayatından ayrılmak zorunda kalmak ve sıradan işlerini bile bir başkasının yardımı olmadan yapamamak ile bakıma muhtaçlık, yaşamın sonu olarak nitelendirilebilmektedir. Ancak durumun böyle olmaması gerekmektedir (Tufan, 2003: 101).

Yaşlılıkta "bakım" olarak adlandırılan durum, genellikle olumsuz bir çağrışım yapmakta ve çoğu zaman "bakım yükü" ya da "bakım sorunu” olarak kullanılmaktadır. 
Yaşlılıkta ortaya çıkan bakım ihtiyacının, bakım alması gereken kişi, bakım verecek kişi ve kurumlar ile devlet ekseninde değerlendirilmesinde fayda vardır. Çünkü bakım sorunu sadece bir kesimi ya da kişiyi değil; genel olarak toplumu ilgilendirir niteliktedir.

Durum yaşl1lar açısından değerlendirildiğinde, yıllarca özgürce ve bağımsız bir yetişkin olarak hayatını geçirmiş olan bir bireyin, artık kendi hayatını destek olmadan idame ettirebilecek durumda olmaması başlı başına bir trajedidir.

Durum yaşlı açısından değerlendirildiğinde, yaşlı bireyler, kendi günlük yaşantısını idame ettirebilecek gücü bulamama ve başkalarına -ki bu kişiler evlatları bile olsa- bağımlı olma endişesi yaşamaktadır. Yaşlanan kişiler, özellikle evlatlarına muhtaç olmaktan korkmaktadır. Evlatlarına yük olacağı düşüncesi ya da isteklerini açıkça dile getiremeyeceği endişesi, yaşlının en çok korktuğu durumlardan biridir (Saygılı, 2011: 111-112). Bilindiği gibi, kırsal alan toplumlarında, geleneksel geniş aile tipi yaygındır. Bu toplumlarda aileler ve bir sosyal destek sistemi olarak toplumun diğer bileşenleri, yaşlıları kendi toplumun içinde korunmasını sağlamaktadır. Oysa kentsel toplumlarda, küçük yaştaki çocukların, engellilerin ve yaşıının bakımı sosyal bir sorun olarak ortaya çıkmaktadır (Çamur Duyan, 2008: 169). Kendi hayatını kurmuş olan çocuklarının evlerine yerleşmek, onların hayatlarının bir parçası hâline gelmek durumu sadece yaşlı kişiler açısından değerlendirilmemelidir.

Yaşlının, kendi çocuğunun evine yerleşmesi, çoğu zaman üç kuşağın bir arada yaşadığı yapıyı da beraberinde getirmektedir. Çalışma hayatının içinde aktif olarak bulunun ve artık bakım vermek gibi yeni bir misyon üstlenen yaşlı kişinin çocukları, kendi çocuklarının da birtakım ihtiyaçlarını karşılamak zorundadır. Geç yetişkinlik döneminde yaşanan bu durum, "sandviç kuşağı” (Bozkurt, 2015: 131) kavramı olarak adlandırılmaktadır. $\mathrm{Bu}$ durum pek çok sorunu ortaya çıkarabilmektedir.

Birçok toplumda, yaşlılıkla ilgili çeşitli politikalar geliştirilmektedir. Yaşlının bakımını üstenen kadınların yaşam koşullarındaki zorluklardan manevi kayıplarına kadar pek çok konu gündeme gelmektedir. Manevi kayıpların giderilmesi elbette her zaman mümkün olmamaktadır. Ancak maddi kayıpların giderilebilmesi için pek çok uygulama devreye sokulmaktadır. Örneğin, Danimarka'da yaşlıya bakım hizmeti veren kişilere, profesyonel bir bakıcıya ödenen maaş kadar aylık bağlanmaktadır. Almanya'da ise, aile fertlerinden birinin bakımını üstlenen kişiye, belli bir maaşın bağlanmasının yanı sıra, bakım verdiği süre, emeklilik için gerekli olan gün sayısına sayılmaktadır. Böylece, evde bakıma teşvik edilirken, toplumsal olarak da tasarrufa gidilmiş olunmaktadır (Tufan, 2003: 107). Durum tarihsel 
olarak değerlendirilse, geleneksel geniş ailenin yaygın olduğu dönemlerde, bakım yükü, bakım sorunu gibi kavramların sıkça kullanılmadığını söylemek mümkün olacaktır.

\subsection{Yaşlı İhmal ve İstismarı}

Yaşlı ihmali, yaşlıya bakım veren kişinin, yiyecek veya günlük hizmetlerde bakım sorumluluğunu yerine getirmedeki yetersizliği olarak nitelendirilebilmektedir. İhmal çok geniş bir kavram olmakla birlikte, bazı ihmal örnekleri şöyledir:

- Yaşlının kişisel temizliği, giyinmesi gibi konularda, yaşlıya yardım konusunda yetersizlik,

- Yaşlının reddetmediği durum ve hâllerde, bedensel ve ruhsal sağlık gereksinimlerini yerine getirmede yetersizlik,

- Yaşlının fiziksel ya da sağlık güvenliğini sağlamada yetersizlik (Uysal, 2002: 45).

Yaşı ihmali, sadece maddi koşulları değil aynı zamanda manevi durumu ve ihtiyaçları da içeren bir konudur. İhmal ve istismarın birbirinden ayrılması söz konusu olsa da aslında her ihmal, aynı zamanda yaşlıya yönelik bir istismardır. Yaşlının bakım ihtiyacının karşılanması, ona manevi olarak destek olunması, yaşlının yaşam kalitesini ve hayattan aldığı doyumu da doğrudan etkilemektedir. İhmal ve istismar olayları, insan onuruna yakışır bir hayat sürmesi için yaşlının karşılaşmaması gereken durumların arasındadır.

Türk Ceza Kanunu'nun (26.09.2004 tarihli) 97. maddesinde; "Yaşı veya hastalığ1 dolayısıyla kendini idare edemeyecek durumda olan ve bu nedenle koruma ve gözetim yükümlülügü altında bulunan bir kimseyi kendi hâline terk eden kişi, üç aydan iki yıla kadar hapis cezası ile cezalandırılır" hükmü yer almaktadır. 98. maddede ise; Yaşı, hastalı̆̆ı veya yaralanması dolayısıyla ya da başka herhangi bir nedenle kendini idare edemeyecek durumda olan kimseye hâl ve koşulların elverdiği ölçüde yardım etmeyen ya da durumu derhâl ilgili makamlara bildirmeyen kişi, bir yıla kadar hapis veya adli para cezası ile cezalandırılır" hükmü yer almaktadır.

Yaşlılara yönelik hizmetlerin üretildiği örgütlenmelerin merkezi olan ASPB tarafından yayımlanan, 08.06.2011 tarihli, ASPB’nın Teşkilat ve Görevleri Hakkında Kanun Hükmünde Kararnamenin 2/d fikras1; "engellilerin ve yaşllların her türlü engel, ihmal ve dışlanmaya karşı toplumsal hayata ayrımcılı̆̆a uğramadan ve etkin biçimde katılmalarını sağlamak üzere; ulusal politika ve stratejilerin belirlenmesini koordine etmek, engellilere ve yaşlılara yönelik sosyal hizmet ve yardım faaliyetlerini yürütmek, bu alanda ilgili kamu kurum ve kuruluşları ile gönüllü kuruluşlar arasında işbirliği ve koordinasyonu sağlamak” şeklindedir. 
ILO'nun 1980 tarihinde yayınlamış olduğu, 162 sayılı Yaşlı İşçiler Tavsiye Kararı'nda geçen ifadelere göre; yaşıı olmasına rağmen hâlâ aktif çalışma hayatına katılan bireyler; herhangi bir yaş ayrımcılığına maruz kalmadan, çalışan diğer bireylerle aynı fırsat ve koşullarda ayrıca aynı muameleleri görme hakkına sahiptir (madde 4/c). Bu karar, yalnızca mevcut yaşlıları değil; yaşları ilerlediği zamanlarda istihdamda ve mesleklerinde bu sebeple çeşitli güçlüklerle karşılaşabilecek her çalışan için geçerlidir.

Yaşlı bireylerin fiziksel, psikolojik ve sosyolojik olarak değişen konumları ve özellikleri de istismara açık olmalarının nedenlerindendir. Güçten düşme, duygusal yoğunluğun artması, toplumsallaşma ihtiyacını yeterince karşılayamama durumları, yaşlıların birçok konuda savunmasız kalmasına sebep olmaktadır. Yine maddi gelirde azalmaya ya da aktif olarak çalış(a)mamaya bağlı olarak, tamamen maddi bağımlılık yaşamaları ya da varsa maaşlarını tek başlarına değerlendirememelerinden dolayı, maaşlarına el konulması gibi durumlar da yaşlı ihmal ve istismarı konusunda üzerinde durulan noktalardandır.

Birçok araştırmacı, yaşlı ihmal ve istismarının sebeplerini açıklamak için farklı kuramlar ortaya koymaya çalışmışlardır. Bunların bazıları özellikle bakım vericinin fazla yük üstlenmesinden dolayı ortaya çıkan özelliklerine vurgu yapmaktadır. Kuramlardan bazıları, şiddetin uygulanmasının altında yatan asıl nedenin, şiddet davranışının öğrenilmesi olduğunu iddia etmektedir. Diğer bazı kuramlar, şiddet davranışını; ilişkilerdeki güç dengesizliğine, yaşlıların özellikle politik-ekonomik anlamda marjinalleşmesine ve çeşitli çatışmaların yaşanmasına bağlamaktadır (Çamur Duyan, 2008: 155).

\section{ARAŞTIRMANIN AMACI, KAPSAMI, YÖNTEMI}

\subsection{Araştırmanın Amacı, Konusu ve Önemi}

Araştırmanın konusu, yaşlanma, yaşlılık ve yaşlıların, kırsal ve kentsel alanlarda nasıl değerlendirildiğinin araştırılmasıdır. Yaşlanmaya, yaşlılığa ve yaşlılara yönelik bakış açısının belirlenmesi, her yaş grubundan insanın normal şartlar altında kaçınılmaz olarak kendilerinin de yaşayacağı bu süreci nasıl gördükleri ve kendi yaşlılıklarıyla ilgili düşünceleri de araştırmanın konusu dâhilindedir.

Türkiye'de artan yaşlı nüfusu hakkındaki çalışmalar birçok farklı alanda gerçekleştirilmektedir. Yaşlanmanın, yaşlılığın ve yaşlıların toplumsal olarak nasıl değerlendirildiği ise, üzerinde durulması gereken noktalardan biridir. Bu araştırmanın amacı, aile yapısı, kültür, sosyo-mekânsal yap1 ve benzeri değişkenler göz önünde 
bulundurulduğunda, yaşlanmanın, yaşlılığın ve yaşlıların günümüzde toplum tarafindan, toplum içinde nasıl konumlandırıldığının ortaya çıkarılmasıdır.

Araştırmanın önemi, genellikle olumsuzlukla nitelendirilen yaşlılık dönemi ile ilgili farkındalık yaratabilmektir. Ayrıca yaşlılıkla ilgili sosyolojik çalışmalar yapılmış olsa da yaşlılığa yüklenen anlamlar ve bu anlamlar çerçevesinde gösterilen davranışların kırsal ve kentsel alanlar özelinde araştırılmasına katkı sağlamak hedeflenmiştir. Araştırmanın özgünlüğü yaşlanma, yaşlılık ve yaşlıların kırsal ve kentsel alanlarda bağımsız değişkenler çerçevesinde incelenmesidir. Bununla birlikte literatürde yaşl1ların yaşl1lık üzerine düşünceleri ya da gençlerin yaşlılığa bakış açılarının değerlendirilmesi gibi çalışmalar mevcut olsa da gençlerin, yetişkinlerin ve yaşlıların bütünsel olarak yaşlanma, yaşlılık ve yaşlılarla ilgili görüşlerini ortaya koyan herhangi bir araştırmaya rastlanılmamıştır.

\subsection{Yöntem}

Yaşlanma, yaşlılık ve yaşlıların nasıl değerlendirildiği konusu, sistematik ve mekanik bir anlayış yerine; çok farklı toplumsal olguların ve bu olguların karmaşıklığının derinlemesine anlaşılmasını sağlayacak bir anlayışla çözümlenmeye ihtiyaç duymaktadır. Bireylerin doğası ve olgular arası bağlantıların kurulabilmesi amacıyla, araştırmada, nicel verilerden elde edilen kuramsal zemini yeterli kabul etme ve tümdengelimci bir yol izleme özellikleri gösteren nicel yöntemler kullanılmamıştır Yüksel vd. 2007: vii).

Araştırmada sosyal bilimlerde nitel araştırma tekniklerinden olan "görüşme" kullanılmıştır. Görüşme tekniklerinden olan derinlemesine mülakatın araştırmanının uygulama kısmında kullanılması uygun görülmüştür.

Araştırmanın yöntemi olarak da içerik analizi yöntemi seçilmiştir. İçerik analizi, bir metodolojisi olan araç ve tekniklerden oluşmakta, araştırmacıya kontrollü yorum yapma imkânı sağlamakta, nesnel, bir sistematiği olan, nicel yollarla betimleme imkânı sunan, önceden belirlenmiş olan bir takım ölçütler çerçevesinde inceleme yapılabilen, anlam çıkarmaya elverişli, niteli nicele dönüştürebilen ve kavramların ölçülmesine fırsat tanıyan bir yöntemdir (Tavşanc1l ve Aslan, 2001: 21-22).

İçerik analizi türlerinden olan kategorik içerik analizi, araştırmanın yürütülmesi için seçilmiş olan yöntemdir ve araştırma verilerinin yorumlanması için kullanılan QSR Nvivo programı ile birlikte yürütülmek için son derece elverişlidir.

\section{ARAŞTIRMA BULGULARININ YORUMLANMASI}


Araştırma, kırsal ve kentsel alanlarda yaşlanma, yaşlılık ve yaşlılar olduğu için, görüşülenlerin temelde kırsal ve kentsel olarak mekânsal farklılıklarına vurgu yapmak uygun görülmüştür. Ancak kırsal ve kentsel alanlarda görüşülenlerin cinsiyetleri, yaşadıkları mekân, yaşları, eğitim durumları, meslekleri, aylık gelirleri, çocuk sahibi olma durumları, bakım tecrübelerine sahiplik durumları; yaşl1lık değerlendirmeleri konusunda belirleyici özelliklerdendir. Verilerin yorumlaması yapılırken, üzerinde durulacak olan değişkenler, yukarıda geçen değişkenlerdir.

Araştırmanın tekniği olarak derinlemesine mülakat, verilerin çözümlenmesinde yöntem olarak kategorik içerik analizinin kullanıldığına daha önce de değinilmiştir. Araştırma nitel verilerden oluşmaktadır ve bu veriler, QSR NVivo10 programı kullanılarak çözümlenmiştir. Görüşmeler, anket formunda ve hazır cevaplarla yapılmadığı için, görüşülenlerin ifadeleri, kullandıkları kelimeler yazıya aktarılırken; değiştirilmemiştir. Görüşmeler esnasında sorulması gereken sorular hazırda bulundurulmuş, sorular sorulduktan sonra elde edilen veriler yorumlama aşamasında tekrar gözden geçirilerek, soru olarak sorulmadığı hâlde, görüşmecilerin üzerinde durduğu ortak noktalar tespit edilmiş ve bu veriler de çözümlemeye dâhil edilmiştir.

Görüşülenlere sorulan sorular çerçevesinde "Yaşl1lığın Algılanması", "Yaşl1lığın Başlama Yaşı”, "Evde Bakım İle İlgili Görüşler”, "Kurum Bakımı İle İlgili Görüşler”, "İstismar ile İlgili Görüşler”, "Kuşak Çatışması ile İlgili Görüşler”, "Yaşlılara Saygı", "Mekâna göre Yaşlılık", "Yaşlıların Günlük Yaşam Aktiviteleri”, "Yaşlılık ve Din” ve "Yaşl1lık Dönemi Değerlendirmesi” ana temaları (nodes) oluşturulmuştur. Görüşülenlerden alınan cevaplara göre alt temalar (örneğin olumlu-olumsuz gibi) ortaya çıkmıştır. Bu alt temalara atılan ifadeler (kodlar) bu kez tekrar gözden geçirilerek deşifre (uncover) edilmiş ve ortak ifadeler doğrultusunda gerekli görülen yerlerde alt temaların altında yeniden alt temalar oluşturularak çözümlemeler yapılmıştır.

Kırsal ve kentsel alanlardaki görüşülenlerin kodlanması konusunda en önemli değişkenler olan cinsiyet, yaş ve yaşanılan mekâna vurgu yapmak için görüşülenler; G1 (Kadın, 20, Kent), G18 (Erkek, 56, Kır) şeklinde kodlanmıştır. Görüşülen kişi, görüşme sırasında aynı konuyla ilgili birden fazla fikir beyan etmişse görüşülen kişinin kodlaması verilmiş ve referanslar1 (R1), (R2) şeklinde belirtilmiştir.

\subsection{Yaşlılığın Algılanması (1. Tema)}


Yaşlılığın algılanması konusu, yaşlılık sürecinden ve yaşlıdan farklı bir durumdur. Görüşülenlere "Yaşlılık denilince aklınıza ilk gelen şey nedir?" sorusu yöneltilmiş ve alınan cevaplar hiçbir yönlendirmeye tabi tutulmamıştır. Alınan cevaplar, "Olumlu" ve "Olumsuz" iki alt tema altında deşifre edilmiştir.

Yaşlılık denilince akla ilk gelenler genellikle tek kelime ya da cümle hâlinde ifade edilmiştir. Ardından yapılan açıklamalarsa ifadelerin deşifre edilmesini kolaylaştırmıştır. Görüşülenlerin ifadelerinden olumlu olanların deşifresi 4 kategori hâline getirilmiştir. Bunlar “Emeklilik”, "Boş Zamanların Artması”, “Tecrübe”, "Saygı Görme”dir.

Yaşl1lık denildiğinde akla ilk gelen düşüncelerin neler olduğu ile yapılan sorgulamanın ardından olumsuz olarak değerlendirilen kelimeler ya da cümleler temel alınarak 3 kategori hâlinde deşifre yapılabilmiştir. Bunlar; "Fiziksel Yetersizlikler”, "Muhtaçlık”, "Yalnızlık”dır.

$\mathrm{Bu}$ temanın altında görüşülenlere "Kendinizi yaşlı görüyor musunuz?” sorusu yöneltilmiştir. Görüşülenlerden "Görüyorum” ya da "Görmüyorum” şeklinde yalnızca iki cevap alındığı için kategori hâlinde deşifre yapılmaya çalışılmamıştır. Görüşülenlerin bazılarından bu soruya yönelik herhangi bir cevap alınamamıştır. Cevap vermeyenler genellikle yaşlarını söylemiş, yaşlı olup olmadıklarıyla ilgili herhangi bir görüş bildirmemişlerdir. Görüş bildirmeyenler; daha çok 18-35 yaş aralığındaki bireylerdir. Cevap verenlerin büyük bir çoğunluğu, kendilerini yaşlı olarak görmediklerini söylemiştir.

Ancak araştırmada dikkat çeken bir durumla karşıllaşılmış ve kendilerini yaşlı görmediğini söyleyenlerin bir kısmı, görüşme sırasında yaşlılardan bahsederken kendileri üzerinden örnekleri sıklıkla kullanmışlardır. Sözel olarak kendilerini yaşlı görmediklerini söyleyenlerin bir kısmının aslında yaşlılığı içselleştirdiği sonucu çıkarılmıştır.

Tema kapsamında "Yaşlanmaktan korkuyor musunuz?" sorusu kendini yaşlı olarak gördüğünü belirten kişilere yöneltilmemiştir. Görüşülenler, bu soruyu da "korkuyorum” ya da "korkmuyorum" şeklinde cevapladıkları için bu soruyla ilgili görüşmeler için model oluşturma ihtiyacı hissedilmemiştir. Cevapların nicel değerlendirmesinden çok, yaşlanmaktan korkma ya da korkmamaya sebep olan faktörler önem kazanmıştır.

Yaşlanmaktan korkmadığını söyleyenlerin bir kısmı yaşlanmanın kaçınılmaz bir son olduğu düşüncesini de gerekçelerinde sunmuşlardır. Aynı zamanda görüşülenler, sağlıklı yaşlanmayı başaracaklarını düşünmekte ve bu sebeple yaşlanmaktan korkmadıklarını da dile getirmektedir. 
Yaşlanmaktan korktuğunu ifade eden görüşülenlerin bir kısmı, yaşlanınca yaşayacakları muhtaçlıktan, fiziksel yetersizlikten ve tek başlarına hayatlarını idame ettirebilecek güçlerinin kalmamasından korktuklarını da belirtmişlerdir.

\subsection{Yaşlılığın Başlama Yaşı (2. Tema)}

Çeşitli yaşlılık tanımlarıyla birlikte, bireylerin yaşlı olarak tanımlanabileceği yaş sınırları olsa da toplumun içinde yer alan kişilerin, bu yaş sınırını kaç olarak ve hangi ölçütlere dayanarak belirlediği araştırma için önemli bir veridir.

Bu bağlamda, resmi ölçütler göz ardı edilerek görüşülenlere, “Bir insan kaç yaşından itibaren yaşll sayllabilir?" sorusu sorulmuştur.

Alınan cevaplar 4 kategoride deşifre edilmiştir. Resmi yaşlılık sınırı olan 65 yaş kıstas alınarak bu kategoriler; "65 altı”, “65 üstü”, "Kendini Yaşlı Hissettiğinde” ve "Elden Ayaktan Düştüğünde"dir.

Araştırma verilerine benzer şekilde, yaşlılığın başlamasının belli kriterlere bağlandığı çalışmalara da rastlanılmıştır. Yapılan bir çalışmada (Bayraktar, 2015: 36) "Yaşlılık nasıl başlar?" sorusuna verilen cevaplardan ön plana çıkanları; "Fiziksel zayıflamayla", "Yavaşlayınca", "Hissedilince” ve "Ortalama 60 yaşına gelindiğinde” olmuştur.

\subsection{Evde Bakım İle İlgili Görüşler (3. Tema)}

Görüşülenlere "Yaşlıların evde bakım alması (bakılması) konusunda ne düşünüyorsunuz?" sorusu yöneltilmiş ve alınan cevaplar herhangi bir yönlendirmeye tabi tutulmamıştır. Daha önce belirtildiği gibi görüşülenlerden hiçbirinin evde bakım maaşından bahsetmemesi dikkat çekici bir noktadır. Yapılan bir araştırmada (Gönüllü Taşkesen, 2012: 77), "Devletin verdiği destek (evde bakım maaşı) yaşlıların kendi evlerinde ve kendi yakınları tarafından bakılmasına teşvik niteliğindedir. Ancak görüşülenin tamamı, yakınlarına bakmalarının sebebinin sadece devletin verdiği destek olmadığını belirtmiştir. Bu sonucun daha çok Türk aile yapısından kaynaklandığı sonucuna ulaşılmıştır.” ifadesi yer almaktadır.

"Evde Bakım" olumlu ve olumsuz iki başlıkta toplanmış ve olumlu olarak değerlendirilebilen cevaplar genel itibariyle "Gelenekler”, "Aile Bağları”, “Alışık Olunan Ortam”, başlıklarında deşifre edilmiştir.

Yaşlılara evde bakım vermenin zorluklarının da olduğunu düşünenlerin, bu konuda verdikleri cevapların deşifresi; "Düzenin Bozulması", "Yoğun Çalışma Temposu" ve “Çatışma” olarak üç kategoride genellenmiştir. 
Evde bakım, pek çok yönü olan bir konudur. Bakım alan kişinin ekonomik, psikolojik, sosyal, fiziksel durumundan; bakım veren kişinin cinsiyetine, çalışma durumuna, bakım yüküne, sosyal aktivitelerine, aile ilişkilerine kadar pek çok alanı etkilemektedir. Türk toplumunda aile yapısında bazı değişiklikler olsa da aile kavramı önemini hâlâ korumaktadır. $\mathrm{Bu}$ sebeple yaşlılara bakım verme konusu, bakım verenler için olumsuzluklar içermesine rağmen genel olarak olumlu bir eğilim göstermiştir.

Evde bakım sorusu sorulduğunda neredeyse hiç kimse ASPB tarafindan sağlanan maaşı söz konusu etmemiştir. Bununla birlikte, soru iki farklı şekilde algılanmıştır. Daha çok yaşlının çocuklarının yanına yerleşmesi hâlinde evde bakılması şeklinde değerlendirilirken, bir kısım görüşülenler ise yaşlının kendi evinde bakılması olarak değerlendirmelerini yapmıştır.

Tema kapsamında sorulan "Kimin Daha İyi Bakım Vereceği” sorusunun cevapları; “Kız Çocuk”, “Erkek Çocuk”, ve "Her İkisi De” olarak sınıflandırılmıştır.

Yaşlıya evde bakım hizmeti hakkında yapılan bir çalışmada (Gönüllü Taşkesen, 2012: 53), evde bakım maaşı karşılığında evde bakım hizmeti veren, görüşülen 20 kişinin tamamının kadın olduğu sonucu çıkmıştır. Türkiye'de her türlü bakımın aile içinde genellikle kadınlar tarafından sağlandığı bilinen bir gerçekliktir. Ancak bu durum, kişilerin bakım almak istedikleri kişileri belirlemelerinde çok da etkili değildir. Erkekler, daha çok erkek çocuklarının kendilerine bakmalarını isterken; kadınlar, kız çocuklarının kendilerine bakmalarının daha uygun olacağını söylemiştir ancak bakımın çok yönlü bir kavram olmasını es geçerek yalnızca mahrem konularda bakımı düşünerek soruyu cevaplamışlardır. Oysa günümüzde hâlen ev işlerini yapan kişiler, genellikle kadınlardır. Bakım kavramının içinde yaşlının yemeğinden, düzeninden, kıyafetlerinin temizliğinden, kişisel bakımına kadar pek çok konu bulunmaktadır. Soruya cevap verenlerin pek azı; yemek yapmak gibi eylemleri bakımın içine dâhil etmiştir.

\subsection{Kurum Bakımı İle İlgili Görüşler (4. Tema)}

Kurum bakımı, yaşlılara sağlanan önemli firsatlardan biridir. Araştırmada, kurum bakımı denildiğinde görüşülenlerden alınan bilgiler doğrultusunda akla öncelikli olarak huzurevlerinin geldiği sonucuna ulaşılmıştır. Görüşülenlere yaş gruplarına, yaşadıkları alanlara ya da eğitim durumu gibi değişkenlere göre "Kurum bakımı hakkında ne düşünüyorsunuz?" ya da "Yaşlılara bakım veren yerler sizce nasıl?" sorusu sorulmuştur. 
Alınan cevaplara göre alt temalar oluşturulmuş ve bu temalar öncelikle "Olumlu" ya da “Olumsuz” şeklinde kategorize edilebilmiştir.

Kurum Bakımını olumlu olarak değerlendirenlerin cevapları genel olarak 4 kategoriye ayrılmış ve "Yaşlının Bakım Alabilmesi, "Başkalarına Yük Olmamak", "Yaşlının Düzeni”, "Yaşıtlarla Birlikte Olmak" üzerinde yoğunlaşmıştır.

Kurum Bakımı ile ilgili olumsuz görüş bildirenlerden alınan cevaplar 6 başlık hâlinde deşifre edilmiştir. Olumsuz olarak nitelendirilebilecek değerlendirmelerin arasında ise; “Geleneklere Aykırılık”, “Aile Bağlarının Kopması”, "Şiddet”, “Kötü Şartlar”, "Mahalle Baskısı” ve “Olumsuz İmaj” vardır.

Görüşülenlerin, kurum bakımı ile ilgili düşüncelerinden sonra, kendilerinin kurum bakımı almayı isteme durumları sorgulanmıştır. "Siz yaşlandı̆̆ınızda kurum bakımı almayı ister misiniz?" ya da "Yaşlanınca yaşlıların bakıldı̆̆ yerlere gitmek ister misiniz?" şeklinde sorulan soru karşısında alınan cevaplar 4 alt temaya ayrılmış ve "İstiyorum”, "İstemiyorum”, "Kararsızım”, "Bakan Olmazsa Giderim” şeklinde deşifre edilmiştir.

\subsection{Yaşlı İhmal ve İstismarı (5. Tema)}

İhmal ve istismar konusuyla ilgili sorulan sorulara alınan cevaplar öncelikle "Var" ya da "Yok" şeklinde incelenmiştir. Cevaplar deşifre edilirken olmadığını ifade edenler için çeşitli alt temalar oluşturulmamıştır. Olduğunu ifade edenlerin de literatürdeki sınıflamaya sadık kalınarak sınıflandırması yapılmıştır. Yani "Var" diyenlerin verdikleri cevaplar; "Ekonomik İstismar", "Fiziksel İstismar", "Duygusal/Psikolojik İstismar" ve "Cinsel İstismar” şeklinde ayrılmıştır. Ancak görüşmelerden sonra verilen cevaplar incelendiğinde, bütün istismar türlerine referans bulunmakla birlikte yalnızca cinsel istismarın olduğunu söyleyen hiç kimse olmamıştır.

\subsection{Kuşak Çatışması (6. Tema)}

Görüşülenlerin bireysel özelliklerine göre; "Günümüzde kuşak çatışmasının yaşandığını düşünüyor musunuz?" ya da "Sizce gençlerle yaşlılar anlaşabiliyorlar mı?" soruları sorulmuş ve cevaplar konusunda yönlendirme yapılmamıştır.

Kuşak çatışması olup olmadığıyla ilgili sorulan sorular, öncelikle "Var" ve "Yok" olarak iki alt tema hâlinde belirlenmiştir.

"Var" alt temasına dâhil edilen ifadeler "Yaş Fark1", "Görüş Farklılıkları", “Teknolojinin Gelişmesi”, "Yaşlıları Cahil Görme”, "Yaşlıların Tecrübelerine Önem 
Vermeme" şeklinde deşifre edilmiştir.

\subsection{Yaşlılara Saygı (7. Tema)}

Bu tema oluşturulurken, görüşülenlere "Günümüzde yaşlılara saygı duyuluyor $m u$ ?" sorusu yöneltilmiştir. Alınan cevaplar yalnızca "Var" ve "Yok" olarak sınıflandırılmış ve herhangi bir model oluşturmaya çalışılmamıştır.

Görüşmelerde dikkat çekici olarak, yaşlılara saygının sorulduğu görüşmeciler, yaşl1lara olan saygıyı, günümüzle geçmişi kıyaslayarak anlatmaya çalışmıştır.

\subsection{Mekâna Göre Yaşlıılık (8. Tema)}

“Mekâna Göre Yaşlılık” teması öncelikle iki alt temaya ayrılmıştır. Bunlar; "Kentsel Alanda Yaşlılık" ve "Kırsal Alanda Yaşl1lık”tır. Her iki mekân için de olumlu ve olumsuz olarak nitelendirilebilen ifadelere dayanılarak yeniden alt temalar oluşturulmuştur.

Kentsel alanla ilgili görüşmelerden edinilen ifadelerle öncelikle "Olumlu” ve “Olumsuz" olarak iki alt tema oluşturulmuştur. Kentsel alanlarda yaşlıların çeşitli nedenlerle daha rahat bir yaşl1lık geçirdiğini düşünen görüşülenlerden alınan cevaplar bir araya getirilmiştir. Olumlu olduğu yönünde görüş bildirenlerin cevapları, "Ekonomi”, "İmkânların Fazlalığı", "Sosyal Çeşitlilik” şeklinde üç başlık altında deşifre edilebilmiştir. Kentsel alanda yaşayan yaşlıların, mekânsal olarak bu zorluklarla karşılaştıklarını belirtenlerin görüşleri bir araya getirilmiştir. "Olumsuz" olduğu yönünde görüş bildirenlerin cevapları ise, "Ekonomi”, "Hareketsizlik", "Yalnızlık”, “Güvensizlik”, olmak üzere dört başlık altında deşifre edilebilmiştir.

Görüşmecilerin kırsal alanla ilgili ifadelerinden yola çıkılarak, ifadeler öncelikle olumlu ve olumsuz olarak değerlendirilmiş, daha sonra alt temalar oluşturularak ifadeler, bu alt temaların içine yerleştirilmiştir. Olumlu olduğu düşünülen ifadeler bir araya getirildiğinde, “Giderlerin Az Olması", "Hareketliliğin Devamlılığı”, "Sosyal İlişkilerin Yoğunluğu” ve "Temiz Çevre" şeklinde dört kategoride deşifre yapılabilmiştir. Kırsal alanda yaşlılığın olumsuzluğuna vurgu yapan ifadeler de "İmkânların Kısıtlılı̆̆ı", "Bakımsızlık", "Yıpranma", "Eğitimsizlik”, başlıklarıyla deşifre edilmiştir.

\subsection{Yaşlıların Günlük Yaşam Aktivitelerinin Değerlendirilmesi (9. Tema)}

Oluşturulan "Yaşlıların Günlük Yaşam Aktivitelerinin Değerlendirilmesi” teması, iki alt temaya ayrılarak "Kırsal Alanlar" ve "Kentsel Alanlar" olarak incelenmiştir. Bu noktada dikkat edilmesi gereken husus; örneğin, kırsal alanda yaşayan bireylerin yalnızca kırsal 
alandaki görüşlerinin değerlendirilmesi değil; aynı zamanda kırsal alanda yaşayan bireylerin kentsel alandaki yaşlıların günlük yaşam aktivitelerini de değerlendirmesidir. Tersi de geçerlidir.

Kentsel alandaki yaşlıların günlük yaşam aktivitelerini değerlendirenlerin verdikleri cevaplar; beş kategori altında deşifre edilebilmiştir. Bu kategoriler; "Evde Vakit Geçirirler", “Gezmeye Giderler”, “Kahveye Giderler”, "Yürüyüş Yaparlar”, “Camiye Giderler”dir.

Kırsal alanda yaşlıların günlük yaşam aktiviteleri verilen cevaplar doğrultusunda 6 kategoride deşifre edilebilmiştir. Bu kategoriler şu şekilde ortaya çıkmıştır; "Evde Vakit Geçirirler”, “Komşuya Giderler”, "Kahveye Giderler”, “Torun Bakarlar”, “Toprakla Uğraşırlar”, "Camiye Giderler”.

\subsection{Yaşlılık ve Din (10. Tema)}

Yaşlılığın yaşamın son basamağı olduğu herkes tarafindan kabul görmüş bir durumdur. Yaşamın sonu yaklaştıkça bireylerin aklını kurcalayan konulardan bir tanesi de ölümden sonra olacaklardır. Bu sebeple gençliklerinde yaşamlarının henüz sona ermeyeceğini düşünen bireyler, çeşitli sebeplerle bu sorgulamayı yapmayarak, dini vecibeleri yerine getirmek konusunda isteksiz olabilmektedir. Ayrıca çalışma hayatında aktif olarak yer alan bireyler, zamanın yetersizliği dolayısıyla dinî faaliyetlerden uzak durabilmektedir. Görüşülenlerin bu duruma yoğun olarak vurgu yapmaları, daha önce de bahsedildiği gibi bu temanın ortaya çıkmasına sebep olmuştur.

Görüşülenlerden yaşlanıldığında dinî faaliyetlerin arttığı yönünde referanslar alındığı için, konuyla ilgili alt tema oluşturma ihtiyacı hissedilmemiştir.

Yaşlılık ve din değerlendirmesinde görüşülenlerin, toplumun genelinde gözlemledikleri görüşlerine yer verilmiştir. Baskın olan düşünce yaşlanmayla birlikte ölüm korkusunun insanları sarması ve bu nedenle inançları doğrultusunda ahiretlerine yatırım yapmaları doğrultusundadır. Bu durum aktivite kuramını da destekler şekilde boş zamanların dinî faaliyetlerle doldurulmasını da kapsamaktadır.

Camilere veya dinî toplantılara gitmek; komşuya, gezmeye ya da kahveye gitmek gibi aynı zamanda sosyalleşmeye aracı olan bir durumdur. Özellikle meslek hayatından çekilen, emekli olan insanlar; var olan çevrelerini kısmen yitirdikleri için sosyalleşme ihtiyaçlarını bu yolla karşılayabilmektedir.

\subsection{Yaşlılık Dönemi Değerlendirmesi (11. Tema)}


Görüşülenlerden son olarak yaşl1lık dönemini nasıl gördüklerini ifade etmeleri istenmiştir. Bir süreç olarak düşünüldüğünde yaşlılık döneminin olumlu yönleri, olumsuz yönleri, yaşlılık döneminde meydana gelen davranış değişiklikleri ve Türkiye'deki yaşlılık dönemi ile yurtdışında yaşayan yabancıların yaşlılık dönemi kıyaslaması da bu temanın alt temalarıdır.

Görüşülenlere yaşl11ık döneminin olumlu ve olumsuz yönleri ile bu dönemde bireylerde meydana gelen davranış değişiklikleri soru olarak yöneltilmiştir. Ancak beklenmedik bir şekilde, görüşülenlerin büyük bir kısmı bu dönemi, başka ülkelerde yaşanan yaşlılık dönemi ile kıyaslayarak anlatma yoluna gitmişlerdir.

Yukarıda bahsi geçtiği üzere bu durum, son temanın "Yaşl1lık Döneminin Olumlu Özellikleri”, "Yaşlılık Döneminin Olumsuz Özellikleri”, "Yaşlılık Döneminde Davranış Değişiklikleri" ve "Yaşlılık Döneminin Yurtdışı Karşılaştırılması" olmak üzere 4 alt temaya ayrılması ihtiyacını doğurmuştur.

İlk tema olan "Yaşlılığın Algılanması" temasında, "Yaşlılık denilince aklınıza ilk gelen şey nedir?" sorusu sorulmuştur. Bu tema, ilk temayla benzerlik gösterse de bu temada bir süreç olarak düşünüldüğünde yaşlılığın nasıl değerlendirildiği derinlemesine incelenmiştir. Görüşülenlerin demografik özelliklerine göre "Sizce yaşlılık döneminde güzel olan şeyler nelerdir?" ya da "Yaşlılık döneminin olumlu yönleri nelerdir?" sorusuna verilen cevaplar çerçevesinde 9 kategoride deşifre gerçekleştirilmiştir. Bunlar; "Emeklilik", "Tecrübe", "Sayg1-İlgi Görme”, "Torun Sahibi Olma”, "Sabırlı Olma”, "Sakin Yaşam”, "Yaşam Standartlarının İyileşmesi”, “Aktif Yaşlanma” ve "Yok”tur.

Görüşülenlere demografik özelliklerine bağlı olarak "Yaşlılık döneminin en olumsuz yanları nelerdir?" ya da "Yaşlılık döneminde en kötü şeyler nelerdir?” soruları sorulmuştur. Verilen cevaplar, "Bakıma Muhtaçlık”, "Fiziksel Yetersizlikler”, “Hastalıklar”, "Dışlanma”, "Yalnızlık”, "Yoksulluk”, “Eğitimsizlik”, “Ölüm” kategorilerinde deşifre edilmiştir.

Yaşlılık döneminde davranış değişikliği yaşandığı ile ilgili referans yoğunluğu yaşlılık döneminde yaşlıların davranış değişikliğinin olumsuz yönde olduğu/olacağı üzerinedir. Bu referanslardan çok azı yaşlılığın bireyleri olgunlaştırabileceğinden bahsetmiştir. Yaşlılıkta davranış değişikliği konusunda öne çıkan ifadelerin bir kısmı; çocukluğa geri dönmek, huysuzluk, alınganlık, aksiliktir. 
Yaşlılık Dönemi ile ilgili görüşler alınırken, görüşülenlerin büyük çoğunluğu cevaplarının bir kısmını, Türkiye'deki yaşlıları, yurtdışındaki yaşlılarla kıyaslayarak vermişlerdir.

Araştırmada yer alması düşünülmeyen bu tür bir kıyaslama, sahadaki verilerin fazlaca olmasından dolayı araştırmaya dâhil edilmiştir.

Görüşülenlerin, Türkiye'deki yaşl1ları ve yaşl1lığı nasıl değerlendiklerini görmek açısından; yurtdışındaki yaşlılardan örnekler verilmesi olumlu sonuçlar doğurmuştur. Görüşülenlerin büyük bir kısmı, yaşl1lıkta maddi durumun iyi olmasının yaşlılığg olumlu yönde etkileyeceğini görüşmelerin çeşitli yerlerinde ifade etmişlerdir. Yurtdışında yaşayan yaşlıların da ekonomik olarak Türkiye'ye kıyasla daha güçlü olduklarını düşünmektedir. Bunun dışında kültürel olarak yurtdışındaki yaşlıların özellikle turistik gezilerde bulunma alışkanlıklarının olduğunu düşünmektedir. Ayrıca onların aktif ve sağlıklı yaşlanmalarının bir getirisi olarak daha genç göründüklerini de ifade etmişlerdir.

\section{SONUÇ VE ÖNERILER}

Araştırma sonucunda bireylerin yaşlanma, yaşlılık ve yaşlıları değerlendirmelerinin, demografik özellikleri açısından farklılık gösterdiği sonucuna ulaşılmıştır. Hatta bireylerin değerlendirmeleri, tecrübeleriyle de doğrudan ilişkilidir. Evinde muhtaç bir yaşlı bulunan kimse, yaşlılığı ya da yaşlıları muhtaçlıkla değerlendiriyorken, çevresinde gördüğü yaşlı örnekleri genellikle kendi işlerini yapabilen kimseler olan görüşmeciler, yaşlanma, yaşl1lık ya da yaşlıları farklı değerlendirmiştir.

Bireylerin yaşlılığa olan bakış açıları, yaşlılığın başlama yaşıyla ilgili de pek çok farklı görüşün ortaya çıkmasına sebep olmuştur. Görece genç görüşmeciler, yaşlılığın başlama yaşıyla ilgili 65 altı yaşları söyleyebilirken; yaşları ilerlemiş olan görüşmeciler, bu yaşı 65 üstü olarak belirtmeyi ya da herhangi bir yaş telaffuz etmeden başka kriterlerle yaşlılığın başladığını belirtmeyi uygun görmüşlerdir.

Araştırma sonucunda yaşlılığın her iki mekânda da bakım sorunu temelinde bir yük olarak görülebileceği sonucuna ulaşılmıştır. Araştırma konusunda görüşmecilerin en çok üzerinde durduğu konu bakımla ilgili konular olmuştur. Hem evde bakım hem de kurum bakımı, görüşülenlerin yaşl1lıktan korkma durumunda söylediklerini de destekler niteliktedir. Görüşmeciler, demografik özellikleri fark etmeksizin yaşlılıkta muhtaçlığın kötü bir durum olduğunu belirtmişler ancak yine de hemen hemen bütün görüşülenler kendi yaşlısına kurum bakımı aldırmak istemediğinin de altını çizmiştir. Kurum bakımının tercih edilebileceği 
durumlar da genellikle zorunlulukla nitelendirilmiştir. Gerekli olmadığı durumlarda evde bakımın tercih edildiği sonucuna ulaşılmıştır.

Yaşlı ihmal ve istismarı konusu, literatürde gizliliğini korumakta olan bir konu olarak değerlendirilmektedir. Yapılan görüşmeler sonrasında literatürdeki bu bilgiyi destekleyecek ifadelere rastlanmıştır. Görüşülenler, bu durumu yaşamadıklarını, yaşandığı yerler olsa bile bilemeyeceklerini belirtirken; özellikle kırsal alanlarda yaşayan görüşmeciler, yaşadıkları gibi küçük yerlerde istismarın gerçekleşmesi durumunda kırsal alan sakinleri tarafından duruma müdahale edileceğini sıkça ifade etmişlerdir.

Kuşak çatışması konusu, kırsal alanlarda da kentsel alanlarda da rastlanılan bir durum olmuştur. Özellikle kentsel alanlarda yaşayan bireyler, kırsal alanlarda yaşlılara daha fazla saygı gösterildiği fikrine sahip olsa da kırsal alanlarda yaşayan bireyler tarafından bu fikir desteklenmemiş ve kırsal alanlarda da gençlerin yaşlılara eskisi kadar saygı duymadıkları bu sebeple kuşak çatışması yaşandığıyla ilgili görüş bildirmişlerdir.

Kırsal alanlarda da kentsel alanlarda da yaşliların günlük yaşam aktiviteleri büyük oranda benzerlik göstermekte ve görüşülenlerin yaşlanma, yaşl1lık ve yaşlılara yönelik değerlendirmeleri aktiviteler özelinde değerlendirildiğinde “durağan”llğ̆ işaret etmektedir.

Araştırma sonunda bütünsel olarak yaşl1lık dönemi değerlendirildiğinde, daha çok olumsuzluklarla betimlendiği göze çarpmaktadır. Dönemin olumlu özelliklerinin de olduğu belirtilse de sosyal katılımdan, aile ilişkilerine ve hatta yoksulluğa kadar yaşlılık döneminde pek çok sorunla karşılaşıldı̆̆ı görüşmecilerin ifadelerinde yer bulmuştur.

Yaşlıları topluma kazandırabilmek henüz tam anlamıyla başarılabilen bir süreç olamamıştır. Onların toplumdan dışlanmasının önüne geçmek gerekmektedir. Bunun nedeni sadece yaşlılar olmayıp yaşlananlar da olmaktadır. Özellikle iyi organize edilmiş sosyal güvenlik sistemi, geniş bir yelpazeyle hizmet vererek, yaşlılık döneminin ekonomik ve sağlık problemlerine çözüm getirebilir niteliklere taşınmalıdır. Sadece bununla da kalmayıp yaşlılar ve yaşlılığın sosyal entegrasyonunun da sağlar niteliklere getirilmelidir. Bilimsel araştırmalar 1şığında söylenebilir ki; bugünün yaşlılık konusundaki en önemli sorundan sayılabilecek olan bakım ve yardıma muhtaçlık, ilerleyen zamanlarda da yaşlılığın en önemli sorundan biri olmaya devam edecektir. Bakıma muhtaçlık, tek boyutlu bir problem değildir. $\mathrm{Bu}$ durumun gerçekleşmesi hâlinde problemin tüm boyutlarına ayrı çözümler bulunması gerekmektedir. Örneğin bakıma muhtaç hâle gelen bireyin öncelikle kendisiyle, ardından bakım veren aile ya da aile üyeleriyle meydana gelen sorunlar geniş çaplı bir incelemeye ve çözüm sürecine tabi 
tutulmalıdır. Sosyal güvenlik sistemi aracılığıyla, sistem içinde bakıma muhtaç yaşlı ve yaşlının bu durumdan ekonomik, sosyal ya da psikolojik anlamda direkt olarak etkilenen bakım veren kimse bakım sürecini mümkün olduğunca az zararla atlatabilir hâle getirilmelidir. Sosyal güvenlik sistemi bu gerekleri sağladığında yaşlıyı topluma doğrudan entegre edemese de dışlanmasına engel olabilecek özellikleri bir araya getirmiş olacaktır.

Ayrıca daha önce değinildiği gibi henüz tam anlamıyla gün yüzüne çıkarılamayan yaşlı ihmal ve istismar sorununa verilen önemin giderek artıyor oluşu, olumlu bir durumdur. Bu konuyla ilgili toplumsal farkındalık ve duyarlılığın gelişmesi, sorunun çözümü için yeterli olmasa da engellenmesi ya da görülme sıklığının azaltılmasıyla ilgili önemlidir. Bu konuda atılabilecek en önemli adım, toplumsal bilincin artırılmasına yönelik çalışmaların planlanması ve uygulanmasıdır. Yaşlı bireyler, yaşadıkları istismar ya da ihmal durumlarında utanma ya da kendilerini suçlama yollarına başvurabilirler. İhmal ya da istismara uğrayanların bu davranışlara yönelmemesi için birtakım bilgilendirilmelerin yapılması hatta bu sorunlarla baş başa kaldıklarında başvurabilecekleri kurum ve merkezlerin hangileri olduğunun öğretilmesi ve son olarak devlete bağlı birimlerin daha etkin ve işlevsel çalışmasının sağlanması, atılabilecek adımlardan bir kaçıdır.

Araştırmanın sonuçlarının arasında yer alan yaşlılığa yönelik olumsuz algının değiştirilmesi, hem yaşlılar, hem gençler, hem de toplumsal bütünlük için önemli bir konudur. Bireylerin medyadan bu konuda etkilendikleri araştırmayla sabittir. Yaşlanma, yaşlılık ve yaşlılara yönelik düşüncelerin olumlanması için özellikle gazetelerde, dergilerde, radyolarda, dizilerde, reklamlarda, filmlerde, kamu spotlarında kısacası yazılı ve görsel basında çeşitli stratejiler izlenebilir. Ayrıca yaşlıların toplum içinde aktif rol aldıkları etkinliklerin düzenlenmesi de yaşl1lığın görünürlüğünün artması ve toplumsal bütünleşmenin sağlanması için atılabilecek adımlardandır.

Son olarak; yaşlılığın bütünsel bir incelemeye tabi tutulması ve yaşlıların her yönüyle yaşadıkları sorunların ortaya çıkarılması; onlar için geliştirilecek politikaları, onlara götürülecek hizmetleri düzenlemek için büyük önem taşımaktadır. Bu nedenle yaşlanmayı, yaşlılı̆̆ı ve yaşlıların gereksinimlerini tanımaya yönelik çalışmaların farklı alanlarda sürdürülmesi son derece önemlidir. 


\section{KAYNAKLAR}

AKÇAY, C. (2011), Yaşlılık: Kavramlar, Kuramlar ve Yaşlılığa Hazırlık, Kriter Yayınları, İstanbul.

BAYRAKTAR, S. (2015), “Yaşlılık Algısı”, Kalkınma Atölyesi Dergisi, Yı1:1, Sayı: 2, ss. 28-37.

BEILL, B. (2003), İyi Çocuk, Zor Çocuk: Doğru Davranışlar Çocuklara Nasıl Kazandırılır?, çev. Cuma Yorulmaz, Arkadaş Yayınevi, Ankara.

BOND, J. ve LYNNE, C. (2004), Quality of Life and Older People, Open University Press, New York.

BOZKURT, V. (2015), Değişen Dünyada Sosyoloji: Temeller, Kavramlar, Kurumlar, Ekin Yayınevi, Bursa.

ÇAMUR DUYAN, G. (2008), "Yaşlı İstismarı", Psikolojik, Sosyal ve Bedensel Açıdan Yaşlılık, der. Kurtman Ersanl1 - Melek Kalkan, Pegem Akademi Yayınları, Ankara, ss. 155-170.

ÇiLINGGiroĞLU, N. ve DEMirREL, S. (2004), "Yaşl1lık ve Yaşlı Ayrımcılığı”, Türk Geriatri Dergisi, c. 7 S. 4 , ss. 225-23.

GILleARD, C. ve HIGGS, P. (2005), Contexts of Ageing: Class, Cohort and Community, Polity Press, Cambridge.

GÖKSU, T. (2007), Sosyal Psikoloji, Seçkin Yayınları, Ankara.

VICTOR, C. R. (2005), The Social Context Of Aging, Routledge Press, New York.

GÖNÜLLÜ TAŞKESEN, C. (2012), "Türkiye'de Yaşlılık ve Evde Yaşlı Bakımı; Resmi Karar ve Uygulamaların Yerinde Tespiti (Isparta İli Araştırması)", Süleyman Demirel Üniversitesi Sosyal Bilimler Enstitüsü Sosyoloji Anabilim Dalı, Yayımlanmamış Yüksek Lisans Tezi, Isparta.

HALSTEAD M. J. ve - TAYLOR, M. J. (2000), "Learning and Teaching About Values: A Review of Recent Research", Cambridge Journal Of Education, c. 30, S. 2. ss. 169-202.

HOMANS, G. C. (1971), İnsan Grubu, TODAİ Yayınları, Ankara.

İşÇI, M. (2007), Davranış Bilimleri, Der Yayınları, İstanbul.

KALKAN, M. (2008), "Yaşlılık: Tanımı, Sınıflandırılması ve Genel Bilgiler", Psikolojik, Sosyal ve Bedensel Açıdan Yaşlılık, der. Kurtman Ersanlı, Melek Kalkan, Pegem Akademi Yayınları, Ankara, ss. 1-15.

KOÇAK, A. ve TERKAN, B. (2010), Medya ve Yaşlılar: Yaşlıların Medya İzleme Davranışları ve Motivasyonları, Çizgi Kitabevi, Konya.

KRECH, D. ve CRUTCHFIELD, R. S. (1990), Sosyal Psikoloji, çev. Erol Güngör, Ötüken Neşriyat, İstanbul.

MARSHALL, G. (1999), Sosyoloji Sözlüğ̈̈, çev. Osman Akınhay - Derya Kömürcü, Bilim ve Sanat Yayınları, Ankara.

MORGAN, L. A. ve KUNKEL, S. (1998), Aging: The Social Context, Pine Forge Press, California.

PICARD, R. G. (1991), “The Journalist's Role in Coverage of Terrorist Events”, Media Coverage of Terrorism, der. Odasuo Alali - Kenoye Eke, Sage Publications, California, ss. 40-48. 
POWELL J. L. ve LONGINO, C. F. (2002), "Postmodernism Versus Modernism: Rethinking Theoretical Tensions in Social Gerontology”, Journal of Aging And Identity, c. 7, S. 4, ss. 219-226.

SAYGILI, S. (2011), Yaşlılık Psikolojisi, Elit Kültür Yayınları, İstanbul.

T.C. Aile ve Sosyal Politikalar Bakanlığı Aile ve Toplum Hizmetleri Genel Müdürlüğü, 2011, Türkiye'de Yaşlılık Dönemine İlişkin Beklentiler, T.C. Aile ve Sosyal Politikalar Bakanlığı Aile ve Toplum Hizmetleri Genel Müdürlüğü Yayınları, Ankara.

TAVŞANCIL, E. ve ASLAN, A. E. (2001), İçerik Analiz ve Uygulama Örnekleri, Epsilon Yayınevi, İstanbul, s. $21-22$.

TUFAN, İ. (2003), Modernleşen Türkiye'de Yaşlılık ve Yaşlanmak: Yaşlanmanın Sosyolojisi, Anahtar Kitaplar Yayınevi, İstanbul.

UYSAL, A. (2002), “Dünyada Yaygın Bir Sorun: Yaşlı İstismarı ve İhmali”, Aile ve Toplum, c. 2, S. 5, ss. 4349.

YÜKSEL, A. vd. (2007), Nitel Araştırma: Neden, Nasıl, Niçin?, Detay Yayıncılık, Ankara, 2007.

ZENCIRKIRAN, M. (2015), Sosyoloji, Dora Yayınları, Bursa. 